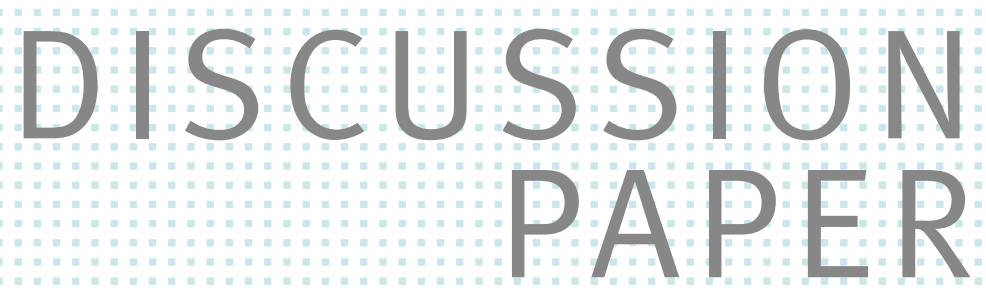

// MAREK GIEBEL AND KORNELIUS KRAFT

Subsidies and Innovation in the Recent Financial Crisis 


\title{
Subsidies and innovation in the recent financial crisis
}

\author{
Marek Giebel $^{\mathrm{a}} \quad$ Kornelius Kraft $^{\mathrm{b}}$
}

Dezember 2021

\begin{abstract}
We analyze the impact of subsidies on R\&D expenditures in the financial crisis and beyond. The financial crisis has led to considerable turmoil in financing and, as a result, to restrictions of firms' access to external financing. Utilizing this fact, we identify and analyze financing constraints in two ways. First, firm financing constraints are determined via their credit rating and second, restrictions from the supply side are identified via the firm's main banks capital reserves. The results of our empirical test imply that R\&D investments of non-subsidized firms decrease during the crisis. This effect is particularly pronounced for firms that are affected by financing constraints on the firm or bank side. Finally, our results imply that subsidies can at least partially compensate for these negative effects.
\end{abstract}

JEL Classification: G01, G21, G24, G30, O16, O30, O31, O32

Keywords: R\&D investment, financing constraints, financial crisis, R\&D subsidies

Acknowledgements: We thank the Deutsche Forschungsgemeinschaft for funding this research by the research grant KR 929/9-1.

\footnotetext{
${ }^{a}$ Corresponding author at: Copenhagen Business School, Department of Economics, mg.eco@cbs.dk

b TU Dortmund, Faculty of Business and Economics, Vogelpothsweg 87, D-44227 Dortmund, ZEW Mannheim IZA Bonn and KU Leuven, Belgium, Kornelius.Kraft@tu-dortmund.de
} 


\section{Introduction}

The importance of innovation activities for the growth and wealth of national economies is well known. While innovations are associated with positive welfare effects, the investment in R\&D is below the socially optimal level (e.g., Hall 2002). Among others, this is rooted in R\&D spillovers to other firms (e.g, Czarnitzki and Kraft 2011; Jirjahn and Kraft 2011), uncertainties in the innovation process (e.g., Hall 2002) and financing constraints (e.g., Hall 2002). Because of their high relevance for welfare, mechanisms are necessary to provide inventives for investments in R\&D. Since financing constraints are among the most prevalent reasons that hamper firm innovation, public subsidies serve an important role to foster these activities (e.g., Zúñiga-Vicente et al. 2014).

Following this argumentation, funding sources like R\&D subsidies have a raison d'être in times when the economy is working well, but could be assumed to be even more important when the financial markets are under tension. Especially in times of financial crises, firms in general and their innovation activity in particular were affected negatively (e.g., Amore 2015; Archibugi et al. 2013a; Archibugi et al. 2013b; Campello et al. 2010; Filippetti and Archibugi 2011; Nanda and Nicholas 2014; Paunov 2012). In these time periods, particularly financial problems of banks exert a negative impact on the innovation activities of their corporate customers (e.g., Huber 2018; Giebel and Kraft 2019; Nanda and Nicholas 2014). Consequently, additional funding sources like R\&D subsidies could be assumed to play an important role in times when financial markets are under tensions.

The aim of this paper is to analyze the effects of subsidies when access to external financing has become more difficult. In particular, we investigate to what extent subsidies can mitigate or completely offset the decline in external financing of $R \& D$ due to financing constraints of firms or banks. This question is analyzed in the context of the financial crisis, as a period when credit supply was severely hampered by problems in the banking sector. Our study 
therefore also adresses the question whether in crisis situations government activities can generate an economic benefit by subsidizing innovation activities.

We combine different data sources to investigate the effect of subsidies and financial constraints of banks and firms on firm R\&D in a difference-in-differences approach. On the firm level we use data from the Mannheim Innovation Panel (MIP), which represents the German contribution to the Community Innovation Survey (CIS). The MIP collects a wide range of information on companies in general (turnover, employment, etc.) and on innovation in particular (e.g. R\&D expenditure). We combine the firm data from the MIP with two additional data sources, which include information on the financial constraints of firms and of banks. First, we add information from Creditreform - the largest credit rating agency in Germany - to account for the creditworthiness of the company. The creditworthiness of companies certainly plays a role when granting loans in times of scarce capital. We take this into account by means of a credit rating. Second, a major advantage of the MIP is that the main bank of the firms can be identified. This information is used by us to determine the financial strength of the banks, which are the firms' main supplier of external financing. ${ }^{3}$ For this purpose, we combine the firm data with bank capital information from Bankscope, compiled by Bureau van Dijk. This enables us determining the individual strength of the respective main banks during the financial crisis according to their pre-crisis capital endowment. Consequently, these two sources allow us to identify a shortage of debt capital, which can therefore be caused by financial restrictions of the banks or financial constraint of the companies.

We first examine the dependence of the firms' $R \& D$ expenditures on subsidies and find a strong positive effect for subsidized firms during the financial crisis. This analysis is then expanded to include financing constraints of firms and banks Thus, in a second step, we

\footnotetext{
${ }^{3}$ Germany is a well-known example for a bank-based economy (see e.g. Berger and Udell 1995, Boot 2000).
} 
distinguish firms into those who are financially constrained or unconstrained according to their credit rating. The results imply that firms with a weak rating show positive effects of subsidies on $R \& D$ expenditures in the financial crisis. For firms with a better credit rating no effect of subsidies on R\&D expenditures in the financial crisis is found. Third, we test for the effects of subsidies on R\&D when we distinguish the firms' main banks according to their capital reserves. The results show that $R \& D$ expenditures of corporate customers with a connection to banks with relatively low reserves react to the changing conditions in the financial crisis. Thus, subsidized firms realize a higher level of $R \& D$ expenditures, while nonsubsidized firms do not. Customers with a link to banks with high capital reserves show no change of R\&D expenditures dependent on subsidies in the financial crisis. Our results imply that $R \& D$ subsidies can offset restrictions by a link to weakly capitalised banks. This is even true for firms with a weak rating. Subsidies can at least partially compensate for the negative effects of a crisis.

Essentially, our study contributes to i) investigations on the impact of firms` constraints on R\&D (e.g. Czarnitzki 2006, Czarnitzki and Hottenrott 2010, Czarnitzki and Hottenrott 2011a,b) ii) studies on the effects of capital reserves of banks on their corporate customers during the financial crisis (e.g. Bundesbank 2009; Holton et al. 2014; Kapan and Minoiu 2018; Puri et al. 2011) and iii) works on the effectiveness of subsidies in general (e.g., Howell 2017) and (iv) the effect of subsidies during the crisis in particular (e.g. Aristei et al. 2017; Brautzsch et al. 2015; Hud and Hussinger 2015). We contribute to these strands of literature by first combining them and second showing that subsidies are an important policy tool to mitigate financing constraints for firm R\&D. This relation holds not only for the often-studied firm financing constraints, but also for bank constraints, which are first investigated in this study. 
The remainder of the paper has the following structure: section two discusses financial constraints and the impact of distortions in the financial sector on the access of companies to external financing and related with this on innovation activities. In the third chapter we describe the data basis as well as the variables and methodology. The fifth chapter presents the results. This is followed by a description of the robustness test and its results. Chapter seven summarizes the results and discusses policy implications of the empirical study.

\section{Subsidies and financing constraints for $R \& D$ in the financial crisis}

\subsection{The financing of innovations}

It is generally acknowledged that financing is an important input factor for innovation (e.g., Hall 2002). Besides the availability of internal financing, also the situation on capital markets affects firm financing in general. Theoretically, capital markets lead to efficient outcomes (e.g., Modiglini and Miller 1958). This, however, is not found in reality, so that outcomes are not as efficient as they are theoretically expected. Usually, serious asymmetric information problems arise and these restrict access to external financing (e.g. Hall and Lerner 2010). Because of their characteristics, this is especially the case for innovation projects (e.g., Hall 2002). For this type of investment, the problem is even more severe as, for example, usually the lending bank has very little possibilities to assess the prospects of success of innovations. Moreover, R\&D projects also offer little collateral, as most of the expenditure is spent on R\&D personnel (e.g., Hall 2002). Therefore it is questionable whether they are basically suitable for external financing or whether they have to be financed entirely from internal resources (e.g. Hall and Lerner 2010, Kerr and Nada 2015). Consequently, innovative firms often find it difficult to obtain loans in general and for innovation in particular. This in result hinders innovation activities. 
However, there may be an indirect link between access to debt finance and innovation investment (e.g., Knudsen and Lien 2014). Firms may be able to obtain debt finance for more secure projects such as for investments in capacity expansions for the production of established products. The internal resources freed up by this can then be used to finance innovation projects. Therefore, the availability of internal and external financing may well affect the innovation behavior of firms.

\subsection{The impact of the financial crisis on firm financing}

The before mentioned problems for innovative firms to obtain financing become even more severe in times of stress on financial markets. It is common knowledge that the financial crisis has hit the banks in particular (e.g., Ivashina and Scharfstein 2010; Puri et al. 2011; Kapan and Minoiu 2018). This was also reflected in credit restrictions for corporate customers, which of course is a problem especially in bank-based economies like Germany. Besides a reduction in the supply of bank loans firms also faced increased costs for external financing in terms of bank credit (e.g. Bundesbank 2009; Holton et al. 2014; Kapan and Minoiu 2018; Puri et al. 2011). As a consequence, innovative firms in particular have had difficulties in financing their projects (e.g. Lee et al. 2015).

However, not all banks were hit equally hard during the crisis. A key factor was the reserves that banks had built up in good times (e.g., Adrian et al. 2018; Gambacorta and Shin 2018; Jiménez et al. 2012; Kapan and Minoiu 2018). The level of accumulated equity or other reserves was a key determinant of the extent of the problems experienced by the individual banks during the crisis (Adrian et al. 2018; Beltratti and Stulz 2012; Berger and Bouwman 2013; Jiménez et al. 2012; Kapan and Minoiu 2018). Higher bank capital makes it possible to compensate for defaults and acts as a positive signal for the strength of the bank (e.g., Buch and Prieto 2014; Diamond and Rajan 2000; Gambacorta and Mistrulli 2004; Holmstrom and Tirole 1997; Jiménez et al. 2012). This reduces agency costs of borrowing (Holmstrom and 
Tirole 1997; Jiménez et al. 2012) which could be approximated by the lending costs on the interbank market (Adrian et al. 2018; Gambacorta and Shin 2018; Kapan and Minoiu 2018; Mingo 1975). Therefore, higher bank capital is correlated with higher credit supply in all times (e.g Buch and Prieto 2014; Gambacorta and Mistrulli 2004), and in particular during the crisis, when banks with sufficient reserves reduced their lending less than others (e.g. Beltratti and Stulz 2012; di Patti and Sette 2016; Gambacorta and Shin 2018; Kapan and Minoiu 2018; Košak 2015). ${ }^{4}$

To sum up, we expect that banks with insufficient reserves reduce their credit supply disproportionately during the financial crisis. This in turn implies that firms that are associated with banks that have formed less capital reserves will have greater difficulties in obtaining debt financing during the crisis than others. Based on the assumption of a direct or indirect relationship between debt financing and $R \& D$, such firms will reduce their activities in this area. Firms that are linked to a bank that accumulated a relatively large amount of capital before the crisis should have fewer or no problems with debt financing. Accordingly, we expect less or no restrictions on $R \& D$ expenditures for such firms.

It is quite plausible that the above-mentioned creditworthiness of firms plays an even higher role when banks themselves get into financing difficulties because of low reserves. This relates to both, credit supply and lending conditions. In that respect, banks could place even more emphasis on the credit rating when selecting those to receive loans. This would give credit rating a special importance in the case of constrained banks and the credit supply would be limited or stricter lending conditions are imposed. Thus, firm financing would be affect by the interaction of two possible restrictions: restrictions on the bank side and constraints by the firms themselves.

\footnotetext{
${ }^{4}$ Bank capital has also been a major factor in the considerations on the structure of the Basel II accord. The Basel II accord in 2007 was based on minimum capital requirements for banks (e.g. Schindele and Szczesny 2016). By this it was intended that banks make provision for risks (e.g. Schindele and Szczesny 2016) and if they were to take greater risks, they should also build up higher reserves.
} 


\subsection{The impact of $R \& D$ subsidies in the financial crisis on innovation}

Subsidies are an important source of financing $R \& D$ in addition to internal and external financing (e.g., Almus and Czarnitzki 2003; Becker 2015; Bronzini and Piselli 2016; Clausen 2009; Czarnitzki and Lopes-Bento 2013; Howell 2017; Lach 2002; Zúñiga-Vicente et al. 2014). This not only relates to the amount of financing available but also to the conducted R\&D activities and its consequences. On the one hand, public R\&D subsidies are applied to fund projects, which are rather uncertain in their nature and might stand in contrast to the firm's incentive to conduct the project with the highest marginal rate of return (e.g. David et al. 2000). On the other hand, funding R\&D by public funds leads to building up capacities of firms and to extending the degree of knowledge input in R\&D projects (David et al. 2000). This could imply rather long-lasting effects from R\&D subsidies on the innovation programme of the firm.

Besides these general impacts on firm innovation, subsidies can also play an important role as a policy measure to reduce the negative effects of financial constraints on R\&D investments (e.g., Hall et al. 2016; Hyytinen and Toivanen 2005; Takalo and Tanayama 2010). Especially in situations which are characterized by difficult access to external financing such as the financial crisis, subsidies arguably could be an important policy instrument to prevent significant drops in $\mathrm{R} \& \mathrm{D}$ expenditures of firms. ${ }^{5}$ One the one hand, this is related to the elevated internal means which stem from the subsidy itself. This in turn allows preventing the allocation of internal funding away from innovation for strategic purposes. On the other hand, if the subsidy serves as a signal to the market for external financing, being a recipient likely leads to better access to credit in terms of credit conditions (e.g., Hottenrott et al. 2018; Kleer 2010; Meuleman and Maeseneire 2012). Thus, both, the higher amount of internal financing and the better access to credit markets counteract negative effects from turbulences on

\footnotetext{
${ }^{5}$ Interestingly, the German Federal Ministry for Education and Research (BMBF) actually raised its budget in response to the crisis (Hud and Hussinger 2015).
} 
financial markets. Consequently, we expect that beneficicaries of $R \& D$ subsidies are less affected from adverse conditions on financial markets in general and financing constraints of banks in particular.

\section{Data and econometric approach}

\subsection{Data and variables}

To investigate the relation between subsidies, financing constraints and $R \& D$, we combine firm data with information about the main banks to which they are affiliated. With respect to the firms we use the Mannheim Innovation Panel (MIP) over the periods 2004 to 2012. The MIP is the part of the Community Innovation Survey (CIS) for Germany. It annually collects information like $\mathrm{R} \& \mathrm{D}$, other innovation related and also general firm data. This data is matched with information on bank balance sheet figures from Bankscope, a databank collected by Bureau van Dijk. We form an annual data base, which consists out of repeated cross sections, since not all firms participate in the survey every year. Our sample is based on firms from manufacturing and knowledge intensive sectors. The relevant industries are NACE Rev 2.0 codes from 5 to 39 and 58 to 66 as well as 69 to 73 . The study is based on a sample of 6,457 firm-years for 2,928 firms.

We use R\&D expenditures as the dependent variable to investigate the effect of financing constraints on innovation activites. This is frequently done by other researchers (e.g., Brown et al. 2012; Czarnitzki and Hottenrott 2011b). We logarithmize R\&D expenditurs to improve their distributional properties. However, we include firms in our sample that do not perform R\&D and therefore our data have zero values. In such cases we apply the transformation $\ln (R \& D+1)$ to retain these observations in the sample.

Our main variable of interest characterizes the firms as subsidy recipient or non-subsidy recipient. We observe this variable in the survey waves 2005, 2007, 2009, 2011 and 2013. In 
these waves, the firms were asked whether they received a subsidy in the previous three years or not. We use this information to construct various treatment indicators, which are utilized in the main analysis and subsequent robustness tests. First, we construct our main treatment variable, which takes unit value when the firm was a subsidy recipient in a specific year and zero else. ${ }^{6}$ For subsequent tests, we define two additional variables: An indicator variable which is assigned value one when the firm was a subsidy recipient in at least one of the two years prior to the crisis $(2005,2006)$ and zero else. The last variable captures the information whether the firm was subsidy recipient in each year until the end of the financial crisis in 2009. Thus, it takes value one if the firms was a subsidy recipient in the financial crisis and before and zero else.

We also include standard variables used to characterize firms, like lagged number of employees in thousands 'Firm size', the square 'Firm size squared', firm age in years 'Firm age' and the square of this variable 'Firm age squared'. The dummy variable 'Group membership' has unit value if the firm is member of a group. International trade is included by the lagged share of exports divided by sales 'Export share', and this variable aims at inclusion of demand-related influences on R\&D expenditures. ${ }^{7}$ The lagged value of sales growth 'Sales growth' is additional information on the financial strength of the firm.

The identification of the financial constraints rooted in the firm itself is implemented by credit rating of the firms 'Rating' similar to the proposal of Carreira and Silva (2010). We use the rating index calculated by Creditreform, the largest German credit rating agency. The index is based on a number of qualitative and quantitative input measures, and takes values from 100 (the best result) to 600 (the worst outcome). The index explicitly aims at the creditworthiness of the rated firms and is therefore well suited for characterizing the financial status of the

\footnotetext{
${ }^{6}$ See Hud and Hussinger (2015) who use a similar approach to define the treatment variable to investigate the effect of R\&D subsidies by the German Federal Ministry for Education Research (BMBF) on R\&D during the financial crisis.

${ }^{7}$ See e.g. Bricongne et al. (2012) and Eaton et al. (2016) who show that exporting activity is correlated with the fall in demand during the financial crisis.
} 
rated entities. ${ }^{8}$ We discard firms from our sample, which already before the crisis had rating values of 500 or above, as this expresses that the firms are about to declare bankruptcy.

This data on the firms is combined with information from the Bankscope database on bank balance sheet measures. This allows us to include several variables on the bank's financial situation in terms of capital availability. In order to secure exogeneity, all variables are based on 2006 values, which implies that they were not affected by the financial crisis. We use the ratio of equity to total assets, which is equivalent to the inverse of the leverage ratio (Adrian et al. 2018; Berger and Bouwman 2013; Jiménez et al. 2012). In accordance with the literature (e.g. Anginer et al. 2016; Bayazitova and Shivdasani 2012; Bitar et al. 2018; Demirguc-Kunt et al. 2013; Kapan and Minoiu 2018, Tran et al. 2016) we use tangible common equity to represent quality of capital., Compared to the raw equity, tangible common equity does not include intangible assets, goodwill and preferred stock (Bayazitova and Shivdasani 2012; Kapan and Minoiu 2018). The ratio of tangible common equity over tangible assets forms the variable 'Tangible common equity'. ${ }^{9}$ Clearly, a higher level of this variable stands for availability of high-quality capital and this implies better ability to absorb losses as well as to withstand shocks (Kapan and Minoiu 2018). A further argument for the use of this variable is that investors prefer this ratio in comparisons to regulatory ratios like the Tier 1 ratio (Kapan and Minoiu 2018).

\footnotetext{
${ }^{8}$ The index is constructed on the basis of a multitude of firm informations like liquidity, balance sheet structure, financing, legal form, ownership structure, industry, prior credit requests, ability to repay credits in time. E.g. Czarnitzki and Hottenrott (2011a) provide a detailed description, how the rating index is genrerated. In addition, we use federal state fixed effects to control for the possible regional variation in the index. For other works which apply this credit rating as information on access possibilities to external capital and therefore as a measure of the financing situation of the firm see for example Czarnitzki (2006), Czarnitzki and Hottenrott (2011a,b). Empirical evidence on this conclusion is provided by Czarnitzki and Kraft (2007), who show that a weaker firm rating is associated with higher interest rate payments.

${ }^{9}$ Ths variable is frequently used in connection of the Basel III requirements (e.g. Yan et al. 2012).
} 


\subsection{Descriptive statistics}

The descriptive statistics for the full sample of firms shown in Table 1, column (1). ${ }^{10}$ About 25 percent of all observations show zero R\&D expenses. On average a firm has 217 employees. The average firm age is approximately 30 years. Related to the financing constraints indicators, the following is observed: The average credit rating has a value of 216 , which implies a good rating evaluation. The Tangible common equity ratio is on average about 4 percent. The capital funds amount at the mean about $6 \%$ of bank assets. The mean and standard deviation of the variables separately for subsidized and non-subsidized firms are shown in columns (3) to (6). The figures imply that subsidized firms are larger, more likely exporters, show a higher degree of firm financing constraints and are related to financially weaker banks. The results for tests on the differences in means shown in column (7) imply that these are statistically significant.

\footnotetext{
${ }^{10}$ See Table A1 and A2 in Appendix A for the distribution of firms over industries and federal states.
} 
Table 1: Descriptive statistics

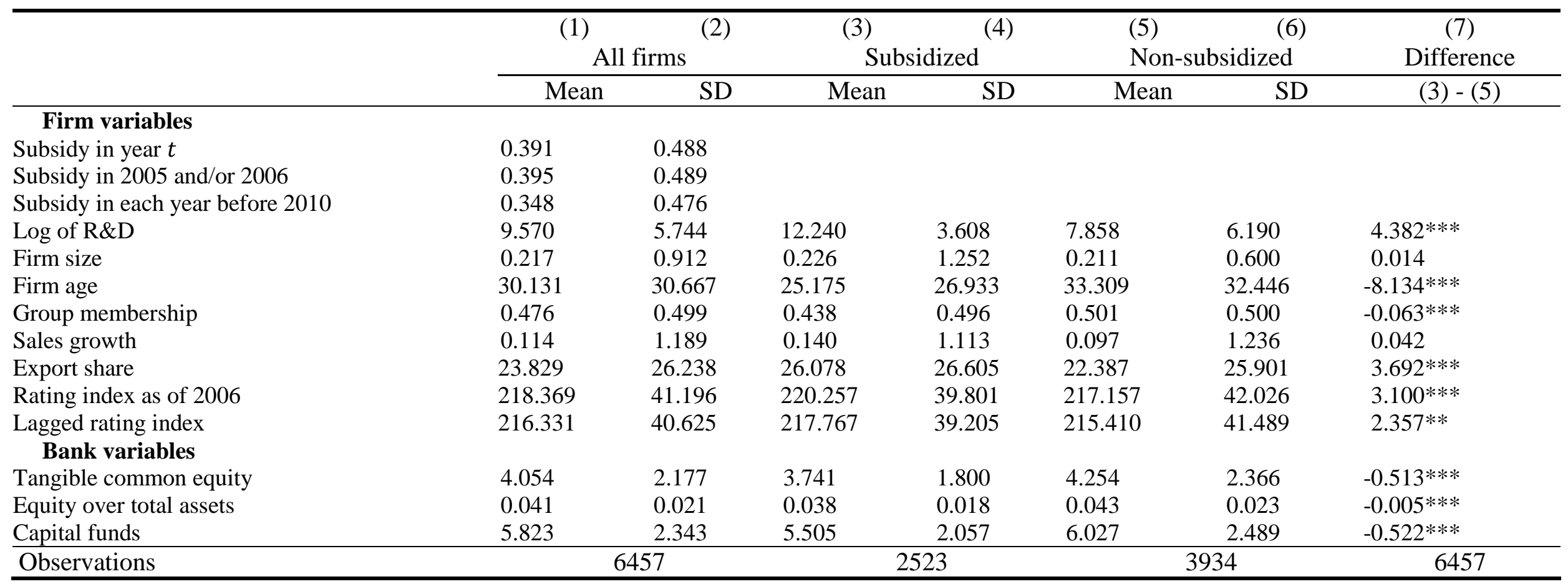

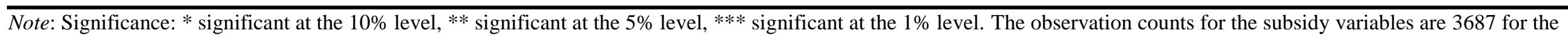
variable 'Subsidy in 2005 and/or 2006' and 4909 for the variable 'Subsidy in each year before 2010'. 
The development of R\&D expenditures for the firms in our sample differentiated according to their subsidization status is shown in Figure 1. It becomes evident that subsidized firms realize higher $R \& D$ expenditures in the time before the financial crisis (pre 2007). In the years 2007 and later, the gap becomes even larger. This already implies two preliminary findings: First, the realized $R \& D$ expenditures before the financial crisis show a parallel movment for subsidized and non-subsidized firms. Second, R\&D expenditures of non-subsidized firms decrease to a stronger degree compared to the subsidized firms.

\section{Figure 1: Mean over time for subsidized and non-subsidized firms}

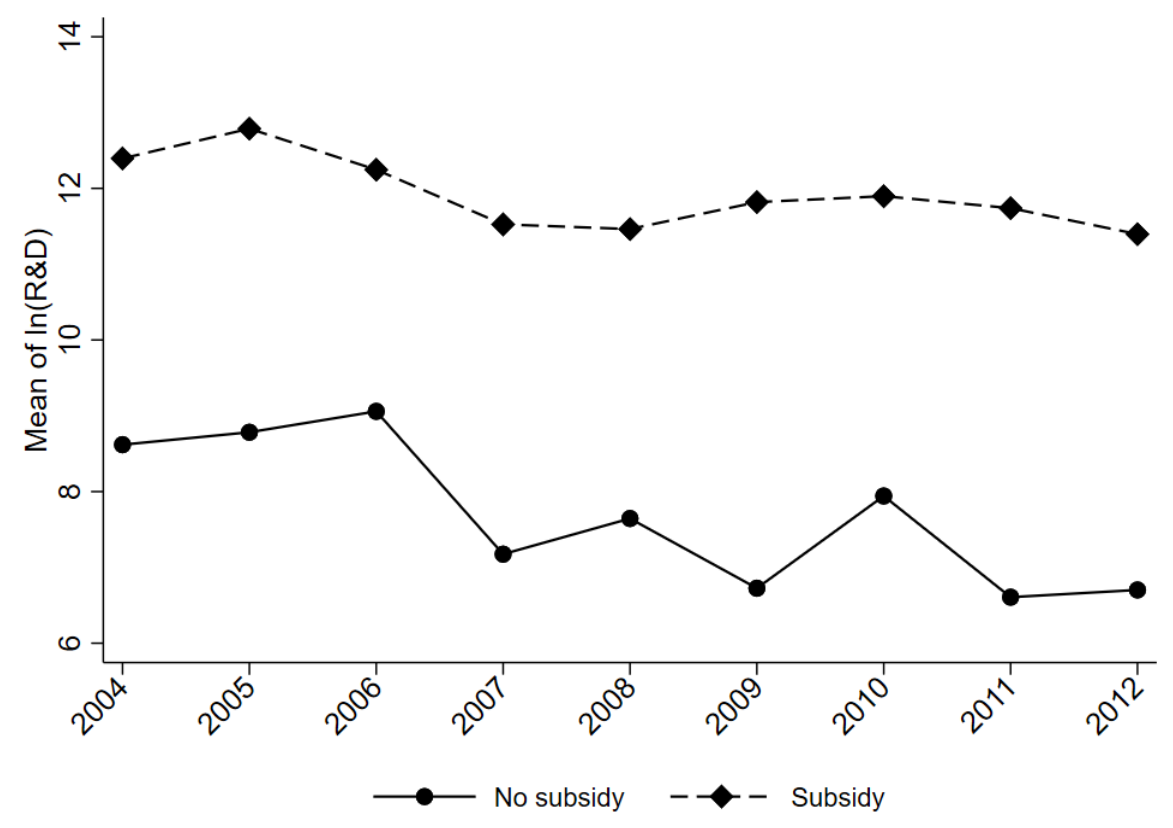

Note: The figure shows R\&D expenditures for subsidized and not subsidized firms over time.

\subsection{Accounting for selection into the subsidy recipient status}

The results in Table 1 imply that there are significant differences in observable firm characteristics between subsidy and non-subsidy recipients. We address this potential selection problem as firms with special characteristics are likely subsidy recipients (e.g. Hud and Hussinger 2015). This selection problem could be rooted in several facts. First, firms that would not be R\&D active without extra funding might select themselves into a subsidy 
program due to the prospect of funded R\&D (e.g., Aguiar and Gagnepain 2017). Second, the choice of applicants by the institution awarding the funds leads to a selection problem. This is rooted in fact that the most promising projects are picked from the pool of potentially funded projects (e.g, Hünermund and Czarnitzki 2019). Consequently, subsidized firms realize different $R \& D$ expenditures than firms, which do not receive a subsidy.

To account for the possible selectivity problem, we apply the inverse probability weighting (IPW) model (e.g. Abadie \& Cattaneo 2018; Imbens \& Wooldridge 2009). This is realized in two steps. First, by use of a probit model the probability of each firm is estimated to be a subsidy recipient or not. In the Appendix B, Table B1, we present the results for the Probit estimation. We use these estimations to obtain the propensity score and drop observations that are not in the region of common support. In the second step, based on the estimated propensity score the inverse probability weight is computed. ${ }^{11}$ Table B2 in Appendix B shows a comparison of the weighted means. It turns out that after weighting there are no significant differences between the means of the two samples. We utilize the calculated weights in subsequent regressions to adjust for possible differences in observable firm characteristics.

\subsection{Identification of the effect of financing constraints on $R \& D$}

To investigate the effect of subsidies and financing constraints on $R \& D$, we start with baseline difference-in-differences regressions weighted by inverse probability weights. Consequently, we apply the following regression:

$$
\begin{aligned}
\ln (\mathrm{R} \& \mathrm{D}+1)_{i t}=\quad \beta_{0} & +\beta_{1} \operatorname{Subsidy}_{i}+\beta_{2} \operatorname{Crisis}_{t}+\beta_{3} \text { PostCrisis }_{t}+\beta_{4} \text { Subsidy }_{i} \times \text { Crisis }_{t} \\
& +\beta_{5} \text { Subsidy }_{i} \times \text { PostCrisis }_{t}+\beta \mathrm{X}^{\prime}+\phi_{i}+\eta_{i}+\varepsilon_{i t}
\end{aligned}
$$

where the dummy variable 'Subsidy' captures whether the firm is a subsidy recipient or not. Further included are indicator variables for the time periods marked by severe turmoil on

\footnotetext{
${ }^{11}$ The inverse probability weight $w$ depends on the propensity score $p s$ and is computed as $w=1 / p s$ for the subsidy recipients and $w=1 /(1-p s)$ for the firms not funded by subsidies.
} 
financial markets. The dummy variable 'Crisis' assumes unit value for the periods 2007 to 2009 and is zero otherwise. Finally, 'PostCrisis' is a dummy variable, which marks the periods after the strong problems on financial markets and takes unit value for the years 2010 to 2012. In this regard the coefficients of the interaction terms, $\beta_{4}$ and $\beta_{5}$, inform about how the relation between $R \& D$ and subsidies reacts to financial constraints if financial markets are under stress (financial crisis), in comparison to the time during (2007-2009) and after (20102012) the financial crisis. In addition, we include a set of control variables $X$ as outlined above. To account for industry and region specific effects, we also include a set of dummy variables for the industry $\left(\eta_{i}\right)$ of the firm and the federal state $\left(\phi_{i}\right)$ the firm is located in.

As mentioned before, a significant part of our observations have zero values for our dependent variable, as these firms do not conduct R\&D. We take account of these corner solutions by the use of a Tobit model (Wooldridge 2010). As it is well known, in case of heteroscedasticity, a standard Tobit model leads to inconsistent coefficients (aside of inconsistent standard errors). In our model Wald tests reject the homoscedasticity assumption. Therefore, we apply the heteroscedastic Tobit model (Greene 2003). This is implemented by a replacement of the usual variance component $\sigma$ by a function $\sigma_{i}=\sigma \times \exp \left(Z^{\prime} \alpha\right)$. We insert the variables size, age and industry dummies into the heteroscedasticity correcting term.

In addition to the pooled average effect, we also determine the heterogeneity over time. For this purpose, we apply the following regression equation

$$
\ln (\mathrm{R} \& \mathrm{D}+1)_{i t}=\quad \beta_{1}+\tau_{1} \text { Subsidy }_{\mathrm{i}}+\sum_{\substack{\mathrm{t}=2004, \mathrm{t} \neq 2006}}^{2012} \tau_{1, \mathrm{t}} \text { Subsidy }_{\mathrm{i}} \times \gamma_{\mathrm{t}}+\sum_{\substack{\mathrm{t}=2004, \mathrm{t} \neq 2006}}^{2012} \gamma_{\mathrm{t}}+\beta \mathrm{X}+\phi_{i}+\eta_{i}+\varepsilon_{\mathrm{i}}
$$

where we include the interaction term Subsidy $\times \gamma_{\mathrm{t}}$ that allows to estimate the yearly cofficients $\tau_{1, t}$. These inform about the yearly change in R\&D expenditures for subsidized firms compared to not subsidized firms with reference to the baseline year 2006. Thus, we analyze two types of heterogeneity: First, testing for the joint significance of the pre-crisis 
interaction terms allows evaluating the validity of the parallel trends assumption. This assumption is necessary to hold to obtain unbiased difference-in-differences estimates. Second, this specification enables us to test whether the effects in the crisis period and beyond are time varying or constant.

As explained above, an essential step of our study is to identify the effect of firm and bank constraints on R\&D expenditures. Thus, we include two possible causes for financial constraints. First, only the financial constraints attributable to the companies are included in the baseline specification via the ratings. To determine whether a firm is financially constrained, we take the rating value as of 2006 , so before the financial crisis took place. ${ }^{12} \mathrm{We}$ define a firm as constrained if it has a credit rating weaker than that of the $25 \%$ of firms with the best ratings scores. ${ }^{13}$ Firms with a rating above this threshold are characterized as unconstrained. Thus, we estimate our baseline regression (1) for firms with low and high firm financing constraints.

Second, the firm information will be supplemented in the next step by the capital resources of the banks. This will allow us to investigate the effects of changes in external financing due to problems of the house banks and their interaction with financing constraints of the firms themselves. We apply bank capital as an indicator for bank balance sheet strength. Empirical studies show that banks with higher capital reserves offer more lending to their customers (e.g. Kapan and Minoiu 2018; Gambacorta and Shin 2018) and are themselves are less vulnerable to default (e.g. Berger and Bouwman 2013) in the recent financial crisis. Based on information from the Bankscope databank we define a bank as being affected by the financial

\footnotetext{
${ }^{12} \mathrm{We}$ use this variable as of 2006 as then our measure is not partly determined by the financial crisis in $2008 / 2009$ itself nor by the coming into force of the Basle II guidelines in 2007. The Basle II guidelines put a higher emphasis on credit risk and the borrower risk is evaluated by ratings (internal or external credit ratings).

${ }^{13}$ This threshold is based on the finding in the literature that firm financing constraints are of high importance for firm innovation (e.g., Hottenrott and Peters 2012; Schäfer and Stephan 2017). See e.g. Hottenrott and Peters (2012) who show the importance of internal funds for financing constraints. Their analysis implies that the latter are impacting innovation negatively already when the firm rating is moderately weak. Moreover, Schäfer and Stephan (2017) show that internal firm funds are of much higher importance for innovation than bank financing.
} 
crisis if its capital endowment is in the lower quartile of all German banks. ${ }^{14}$ This means a bank shows a ratio of tangible common equity, which is below 5.17 percent. Our baseline regression is accordingly divided into firms with high and low capitalization.

\section{Results}

\subsection{Baseline results}

We first analyze the role of subsidies for $R \& D$ in the time before, during and after the financial crisis. The results are shown in Table 2, columns (1) to (4). First, for the crisis period, the size of the interaction coefficients of interest Subsidy $\times$ crisis decrease from column (1) to (4) when additional control variables are included. Second, the interaction term for the time beyond the crisis period Subsidy $\times$ PostCrisis implies that, firms, which are subsidy recipients, also benefit in times after the turmoil on financial markets. The test on the bottom of Table 2 reveals that we cannot reject the null hypothesis that the pre-crisis interaction terms of the subsidy and year variables exert jointly no effect. Thus, the common trend assumption is met in every case.

Moreover, we perform tests to compare the development of R\&D expenditures within groups over time. The first two tests, $T_{1}$ and $T_{2}$, aim at determining if the subsidized firms show a significant different pattern in terms of R\&D expenditures in and after the financial crisis compared to the period before. When applying control variables (columns 2 and 4), the tests reported on the bottom of Table 2, imply that subsidized firms experienced a reduction in $\mathrm{R} \& \mathrm{D}$ expenditures in the financial crisis, but catch up in the post crisis period. For the group

\footnotetext{
${ }^{14}$ See Gambacorta and Shin (2018) for a similar approach. The identification of bank constraints is based on the whole sample of German banks (1452) for which Bankscope offers information. Our matched firm-bank data includes 333 of these banks. Since constrained banks are likely larger and related to more firms, the share of firm-year observations for firms related to a bank having a low or high degree of bank financing constraints differs from the one-quarter to three-quarter definition applied to the bank sample.
} 
of non-subsidized firms, however, the development of $R \& D$ spending decreased in the crisis and pre-crisis period as indicated by tests $T_{3}$ and $T_{4}$.

To sum it up, firms, which receive a subsidy realize higher $R \& D$ expenditures compared to non-subsidized firms in times of turmoil on financial markets and beyond. This coincides with the development of R\&D expenditures depicted in Figure 1. Thus, the effect is rather rooted in the fact that non-subsidized firms experience a decrease in $R \& D$ expenditures, while subsidzed firms maintain their level.

Table 2: Impact of subsidies on R\&D

\begin{tabular}{|c|c|c|c|c|}
\hline & (1) & (2) & (3) & (4) \\
\hline & \multicolumn{4}{|c|}{ Log of R\&D } \\
\hline Subsidy & $\begin{array}{l}4.110^{* * *} \\
(0.338)\end{array}$ & $\begin{array}{l}4.023 * * * \\
(0.322)\end{array}$ & $\begin{array}{l}4.033^{* * *} \\
(0.330)\end{array}$ & $\begin{array}{l}3.985 * * * \\
(0.316)\end{array}$ \\
\hline Crisis & $\begin{array}{l}-1.989 * * * \\
(0.397)\end{array}$ & $\begin{array}{l}-1.768 * * * \\
(0.366)\end{array}$ & $\begin{array}{l}-1.891 \text { *** } \\
(0.376)\end{array}$ & $\begin{array}{l}-1.708 * * * \\
(0.355)\end{array}$ \\
\hline PostCrisis & $\begin{array}{l}-1.849 * * * \\
(0.426)\end{array}$ & $\begin{array}{l}-1.597 * * * \\
(0.392)\end{array}$ & $\begin{array}{l}-1.793 \text { *** } \\
(0.397)\end{array}$ & $\begin{array}{l}-1.612 * * * \\
(0.376)\end{array}$ \\
\hline Subsidy $\times$ Crisis & $\begin{array}{l}1.035^{* * *} \\
(0.484)\end{array}$ & $\begin{array}{l}1.039 * * \\
(0.454)\end{array}$ & $\begin{array}{l}1.072 * * \\
(0.463)\end{array}$ & $\begin{array}{l}1.029 * * \\
(0.440)\end{array}$ \\
\hline Subsidy $\times$ PostCrisis & $\begin{array}{l}1.189 * * \\
(0.499)\end{array}$ & $\begin{array}{l}1.256 * * * \\
(0.468)\end{array}$ & $\begin{array}{l}1.156 * * \\
(0.468)\end{array}$ & $\begin{array}{l}1.213 * * * \\
(0.447)\end{array}$ \\
\hline Constant & $\begin{array}{l}8.307 * * * \\
(0.319)\end{array}$ & $\begin{array}{l}7.582 * * * \\
(0.822)\end{array}$ & $\begin{array}{l}8.024 * * * \\
(1.005)\end{array}$ & $\begin{array}{l}7.544 * * * \\
(1.230)\end{array}$ \\
\hline \multicolumn{4}{|c|}{$H_{0}:$ Subsidy $\times$ year $_{\mathrm{t}}=0 \forall \mathrm{t} \leq 2006$} & 0.299 \\
\hline \multicolumn{5}{|c|}{ Tests for the development of R\&D expenditures (p-value) } \\
\hline $\begin{array}{l}T_{1}: \beta_{0}+\beta_{1}=\beta_{0}+\beta_{1}+\beta_{2}+\beta_{4} \\
T_{2}: \beta_{0}+\beta_{1}=\beta_{0}+\beta_{1}+\beta_{3}+\beta_{5} \\
T_{3}: \beta_{0}=\beta_{0}+\beta_{2} \\
T_{4}: \beta_{0}=\beta_{0}+\beta_{3}\end{array}$ & $\begin{array}{l}0.001 \\
0.012 \\
0.000 \\
0.000\end{array}$ & $\begin{array}{l}0.008 \\
0.198 \\
0.000 \\
0.000\end{array}$ & $\begin{array}{l}0.003 \\
0.013 \\
0.000 \\
0.000\end{array}$ & $\begin{array}{l}0.010 \\
0.116 \\
0.000 \\
0.000\end{array}$ \\
\hline Firm control variables & No & Yes & No & Yes \\
\hline Industry fixed effects & No & No & Yes & Yes \\
\hline Federal state fixed effects & No & No & Yes & Yes \\
\hline Log Likelihood & -35457.005 & -34833.853 & -34906.984 & -34484.177 \\
\hline Left censored obs. & 1589 & 1589 & 1589 & 1589 \\
\hline Uncensored obs. & 4763 & 4763 & 4763 & 4763 \\
\hline Observations & 6352 & 6352 & 6352 & 6352 \\
\hline \multicolumn{5}{|c|}{$\begin{array}{l}\text { The dependent variable is the logarithm or R\&D expenditures as described in Section } 3.1 \text {. The variable of } \\
\text { interest, 'Subsidy' indicates whether a firm is subsidy recipient or not. Included are firm control variables as } \\
\text { described in Section } 3.1 \text {. These are firm size, firm size squared, firm age, firm age squared, firm rating, sales } \\
\text { growth and export share. Cluster-robust standard errors in parentheses, clustered at the firm level. Significance: } \\
* \text { significant at the } 10 \% \text { level, ** significant at the } 5 \% \text { level, } * * * \text { significant at the } 1 \% \text { level. }\end{array}$} \\
\hline
\end{tabular}




\subsection{Effect heterogeneity over time}

In a second step, we estimate equation (2) to determine the heterogeneity of the effect over time. Thus, we include the measure of subsidies and interact this variable with year dummies, with which we identify the possible effects in the individual years. As reference year, we utilize 2006 as this is the last year before the beginning of the financial crisis. The base effect, i.e. the general, in contrast to the annual effects, is measured with the coefficient of the variable 'Subsidies'. The plotted coefficients resulting from this procedure can be found in Figure $2 .{ }^{15}$ There is no significant difference of the coefficients for the years 2002 to 2005 to the baseline year 2006 in the period before the financial crisis. This, again, implies that the R\&D spending of subsidized and non-subisidzed firms behaves similar in the period before the crisis. This is underlined by the rejected null hypothesis of joint significance of these coefficients as shown in Table 2 and Table C1 in Appendix C. For the period after 2007, the following is observed: The annual coefficients of the subsidy variables show that receiving subsidies leads firms to spend higher R\&D expenditures during the financial crisis and in the period right after that in comparions to the non-subsidized firms.

\section{Figure 2: Subsidy $\times$ year interactions for the baseline specification}

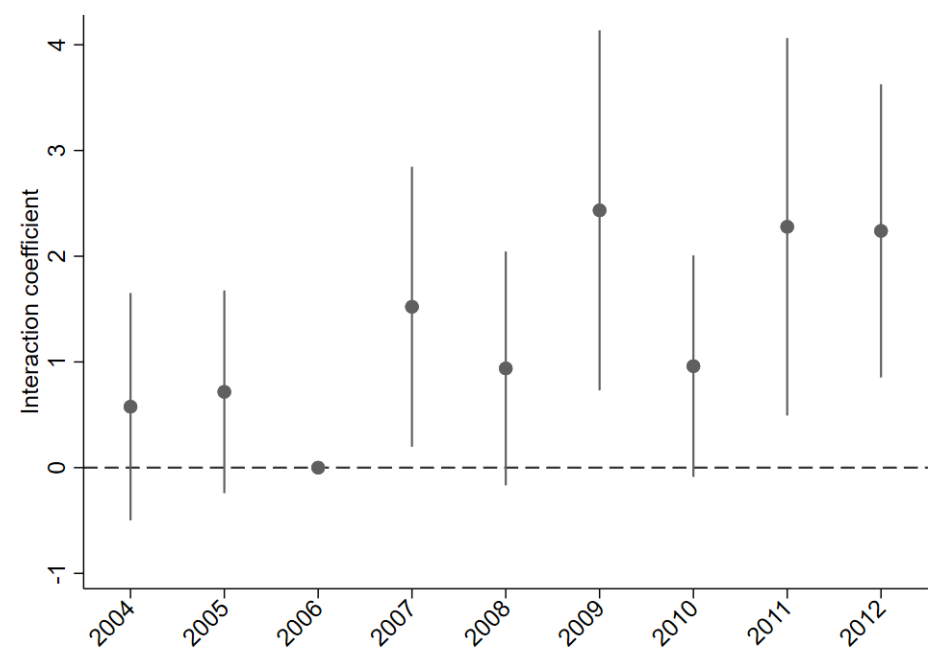

Notes: The figure shows the plotted coefficients of estimating equation (2) for the sample of subsidized and nonsubsidized firms. The year 2006 serves as reference period. The whiskers represent $95 \%$ confidence intervals.

\footnotetext{
15 The detailed regression results from estimating equation (2) are shown in Appendix C, Table C1.
} 


\subsection{Accounting for firm and bank constraints}

In a third step, we determine the effect of subsidies on $R \& D$ for financially constrained and non-constrained firms. For this purpose, we utilize information from the firm and bank perspective as described in Section 3.1. We then estimate equation (1) for firms with low and high constraints separately as described in section 3.4. First, for firm financing constraints, the results are shown in Table 3, columns (1) and (2). They imply that particularly constrained firms benefit from subsidies in the financial crisis and beyond. For the group of firms with low financing constraints, no significant effect in the financial crisis is found. This indicates that these firms do not react more sensitive to subsidies in times of turmoil on financial markets.

Next, we determine financing constraints from the supply side by dividing banks into a high and a low capitalized group according to their capital base. The results of estimating equation (1) for these firm categories are shown in Table 3, columns 3 to 4. Interestingly, for the group of firms associated with relatively poorly capitalized banks (column 4), the same results regarding the effect of the subsidies are found as when the whole sample is used. Subsidies increase $R \& D$ expenditures during the crisis and afterwards. However, this does not apply to firms that are linked to well-capitalized banks (column 3). In the sample of these firms, subsidies have no effect on $R \& D$ investment above that measured in the base category. 
Table 3: Impact of subsidies on $R \& D$ accounting for firm and bank constraints

\begin{tabular}{|c|c|c|c|c|}
\hline & (1) & (2) & (3) & (4) \\
\hline & \multicolumn{4}{|c|}{ Log of R\&D } \\
\hline & \multicolumn{2}{|c|}{ Firm financing constraints } & \multicolumn{2}{|c|}{ Bank financing constraints } \\
\hline & Low & High & Low & High \\
\hline \multirow[t]{2}{*}{ Subsidy } & $2.651 * * *$ & $3.926^{* * *}$ & $3.860 * * *$ & $3.999 * * *$ \\
\hline & $(0.506)$ & $(0.377)$ & $(0.542)$ & $(0.369)$ \\
\hline \multirow[t]{2}{*}{ Crisis } & $-1.359 * *$ & $-1.852 * * *$ & $-1.490 * * *$ & $-1.753 * * *$ \\
\hline & $(0.553)$ & $(0.441)$ & $(0.567)$ & $(0.436)$ \\
\hline \multirow[t]{2}{*}{ PostCrisis } & $-1.187 *$ & $-1.676^{* * *}$ & $-1.844 * * *$ & $-1.553 * * *$ \\
\hline & $(0.627)$ & $(0.457)$ & $(0.682)$ & $(0.458)$ \\
\hline \multirow[t]{2}{*}{ Subsidy $\times$ Crisis } & 0.967 & $1.251^{* *}$ & 0.078 & $1.448 * * *$ \\
\hline & $(0.671)$ & $(0.531)$ & $(0.771)$ & $(0.510)$ \\
\hline \multirow{2}{*}{ Subsidy $\times$ PostCrisis } & 0.613 & $1.577 * * *$ & 1.293 & $1.293 * *$ \\
\hline & $(0.711)$ & $(0.528)$ & $(0.858)$ & $(0.526)$ \\
\hline \multirow[t]{2}{*}{ Constant } & $7.022 * * *$ & $3.964 *$ & $8.153 * * *$ & $7.516^{* * *}$ \\
\hline & $(1.694)$ & $(2.084)$ & $(2.032)$ & $(1.532)$ \\
\hline \multicolumn{5}{|c|}{$H_{0}:$ Subsidy $\times$ year $_{\mathrm{t}}=0 \forall \mathrm{t} \leq 2006 \mathrm{p}$-value } \\
\hline & 0.966 & 0.174 & 0.931 & 0.250 \\
\hline \multicolumn{5}{|c|}{ Tests for the development of R\&D expenditures } \\
\hline$T_{1}: \beta_{0}+\beta_{1}=\beta_{0}+\beta_{1}+\beta_{2}+\beta_{4}$ & 0.303 & 0.050 & 0.008 & 0.264 \\
\hline$T_{2}: \beta_{0}+\beta_{1}=\beta_{0}+\beta_{1}+\beta_{3}+\beta_{5}$ & 0.124 & 0.727 & 0.289 & 0.361 \\
\hline$T_{3}: \beta_{0}=\beta_{0}+\beta_{2}$ & 0.014 & 0.000 & 0.009 & 0.000 \\
\hline$T_{4}: \beta_{0}=\beta_{0}+\beta_{3}$ & 0.058 & 0.000 & 0.007 & 0.001 \\
\hline Industry fixed effects & Yes & Yes & Yes & Yes \\
\hline Federal state fixed effects & Yes & Yes & Yes & Yes \\
\hline Firm controls included & Yes & Yes & Yes & Yes \\
\hline Log Likelihood & -8587.451 & -25525.925 & -9621.124 & -24705.159 \\
\hline Left censored obs. & 305 & 1284 & 506 & 1083 \\
\hline Uncensored obs. & 1249 & 3514 & 1293 & 3470 \\
\hline Observations & 1554 & 4798 & 1799 & 4553 \\
\hline \multicolumn{5}{|c|}{ 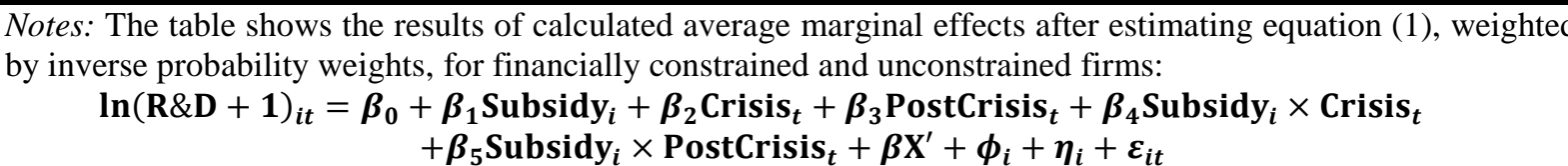 } \\
\hline \multicolumn{5}{|c|}{$\begin{array}{l}\text { The dependent variable is the logarithm or R\&D expenditures as described in Section } 3.1 \text {. The variable of } \\
\text { interest, 'Subsidy' indicates whether a firm is subsidy recipient or not. Included are firm control variables as } \\
\text { described in Section } 3.1 \text {. These are firm size, firm size squared, firm age, firm age squared, firm rating, sales } \\
\text { growth and export share. Firms are defined as having low (high) firm financing constraints if their credit rating is } \\
\text { among (weaker than) that of the } 25 \% \text { of the firms in the sample with the best rating score. For bank financing } \\
\text { constraints, firms are defined as having low (high) constraints if the firm is related to a bank that has a tangible } \\
\text { common equity share which is above (among) of that of the } 25 \% \text { of all German banks in the Bankscope data set } \\
\text { with the lowest reserves. Cluster-robust standard errors in parentheses, clustered at the firm level. Significance: * } \\
\text { significant at the } 10 \% \text { level, ** significant at the } 5 \% \text { level, } * * * \text { significant at the } 1 \% \text { level. }\end{array}$} \\
\hline
\end{tabular}




\section{Robustness tests and extensions}

\subsection{Calculation of the inverse probability weights}

In the first set of tests, we analyze the stability of our approach to changes in the matching algorithm. For this purpose, we apply two modifications to account for potential problems in the overlap of the distribution of the propensity scores for the treatment and control group. First, we trim the inverse probability weights. As proposed by Crump et al. (2009) we discard all propensity score values, which are smaller or larger than the values at $1 \%$ or $99 \%$ of the distribution respectively. From the remainder $98 \%$ of the scores, we calculate the inverspe probability weights as described in section 3.3. The results in panel A of Table 4 are similar to the baseline results. Thus, we can rule out that extreme outliers of our weights are driving the results. In a second test, we further account for a possible mismatch in the overlap of weights, which could bias our results. We follow the suggested approach by Li et al. (2019) and calculate the weights $(w)$ based on the propensity score $(p s)$ as $w_{i}=1-p s_{i}$ for treated and $w_{i}=p s_{i}$ for control units. This approach allows putting emphasis on units with the largest overlap between treated and control units and less weight to those observations in the tails of the distribution ( $\mathrm{Li}$ et al. 2019). The results in panel B of Table 4, again, look similar to the baseline results. 
Table 4: Calculation of the inverse probability weights

\begin{tabular}{|c|c|c|c|c|c|}
\hline & \multicolumn{5}{|c|}{$\log$ of $\mathrm{R} \& \mathrm{D}$} \\
\hline & Baseline & \multicolumn{2}{|c|}{ Firm financing constraints } & \multicolumn{2}{|c|}{ Bank financing constraints } \\
\hline & & Low & High & Low & High \\
\hline \multicolumn{6}{|c|}{ Panel A: Trimming of the inverse probability weights } \\
\hline Subsidy & $\begin{array}{l}3.969 * * * \\
(0.317)\end{array}$ & $\begin{array}{l}2.648 * * * \\
(0.513)\end{array}$ & $\begin{array}{l}3.902 * * * \\
(0.374)\end{array}$ & $\begin{array}{l}3.875^{* * * *} \\
(0.547)\end{array}$ & $\begin{array}{l}3.987 * * * \\
(0.369)\end{array}$ \\
\hline Crisis & $\begin{array}{l}-1.555 * * * \\
(0.339)\end{array}$ & $\begin{array}{l}-1.427 * * \\
(0.566)\end{array}$ & $\begin{array}{l}-1.627 * * * \\
(0.415)\end{array}$ & $\begin{array}{l}-1.479 * * \\
(0.579)\end{array}$ & $\begin{array}{l}-1.557 * * * \\
(0.415)\end{array}$ \\
\hline PostCrisis & $\begin{array}{l}-1.719 * * * \\
(0.373)\end{array}$ & $\begin{array}{l}-1.221^{*} \\
(0.631)\end{array}$ & $\begin{array}{l}-1.807 * * * \\
(0.449)\end{array}$ & $\begin{array}{l}-1.850 * * * \\
(0.690)\end{array}$ & $\begin{array}{l}-1.688 * * * \\
(0.451)\end{array}$ \\
\hline Subsidy $\times$ Crisis & $\begin{array}{l}0.899 * * \\
(0.429)\end{array}$ & $\begin{array}{l}1.044 \\
(0.688)\end{array}$ & $\begin{array}{l}1.061 * * \\
(0.509)\end{array}$ & $\begin{array}{c}0.085 \\
(0.776)\end{array}$ & $\begin{array}{l}1.276 * * * \\
(0.494)\end{array}$ \\
\hline Subsidy $\times$ PostCrisis & $\begin{array}{l}1.344 * * * \\
(0.446)\end{array}$ & $\begin{array}{l}0.610 \\
(0.723) \\
\end{array}$ & $\begin{array}{l}1.754 * * * \\
(0.524) \\
\end{array}$ & $\begin{array}{c}1.303 \\
(0.868) \\
\end{array}$ & $\begin{array}{l}1.464 * * * \\
(0.522) \\
\end{array}$ \\
\hline \multicolumn{6}{|c|}{$H_{0}:$ Subsidy $\times$ year $_{\mathrm{t}}=0 \forall \mathrm{t} \leq 2006 \mathrm{p}$-value } \\
\hline Observations & $\begin{array}{l}0.282 \\
6225 \\
\end{array}$ & $\begin{array}{r}0.986 \\
1516 \\
\end{array}$ & $\begin{array}{l}0.187 \\
4709 \\
\end{array}$ & $\begin{array}{r}0.921 \\
1772 \\
\end{array}$ & $\begin{array}{l}0.244 \\
4453 \\
\end{array}$ \\
\hline \multicolumn{6}{|c|}{ Panel B: Overlap weights } \\
\hline Subsidy & $\begin{array}{l}3.813 * * * \\
(0.318)\end{array}$ & $\begin{array}{l}2.214 * * * \\
(0.477)\end{array}$ & $\begin{array}{l}3.812 * * * \\
(0.373)\end{array}$ & $\begin{array}{l}3.658 * * * \\
(0.550)\end{array}$ & $\begin{array}{l}3.893 * * * \\
(0.370)\end{array}$ \\
\hline Crisis & $\begin{array}{l}-1.689 * * * \\
(0.369)\end{array}$ & $\begin{array}{l}-1.392 * * \\
(0.581)\end{array}$ & $\begin{array}{l}-1.835 * * * \\
(0.447)\end{array}$ & $\begin{array}{l}-1.426 * * \\
(0.614)\end{array}$ & $\begin{array}{l}-1.754 * * * \\
(0.444)\end{array}$ \\
\hline PostCrisis & $\begin{array}{l}-1.664 * * * \\
(0.384)\end{array}$ & $\begin{array}{l}-1.142 * \\
(0.616)\end{array}$ & $\begin{array}{l}-1.814 * * * \\
(0.462)\end{array}$ & $\begin{array}{l}-1.941 * * * \\
(0.741)\end{array}$ & $\begin{array}{l}-1.592 * * * \\
(0.456)\end{array}$ \\
\hline Subsidy $\times$ Crisis & $\begin{array}{l}1.181 * * * \\
(0.430)\end{array}$ & $\begin{array}{l}1.214^{*} \\
(0.686)\end{array}$ & $\begin{array}{l}1.350 * * * \\
(0.510)\end{array}$ & $\begin{array}{l}0.153 \\
(0.738)\end{array}$ & $\begin{array}{l}1.543 * * * \\
(0.505)\end{array}$ \\
\hline Subsidy $\times$ PostCrisis & $\begin{array}{l}1.468 * * * \\
(0.434)\end{array}$ & $\begin{array}{l}0.778 \\
(0.702)\end{array}$ & $\begin{array}{l}1.788 * * * \\
(0.512)\end{array}$ & $\begin{array}{l}1.498 * \\
(0.824)\end{array}$ & $\begin{array}{l}1.511 * * * \\
(0.513)\end{array}$ \\
\hline \multicolumn{6}{|c|}{$H_{0}:$ Subsidy $\times$ year $_{\mathrm{t}}=0 \forall \mathrm{t} \leq 2006 \mathrm{p}$-value } \\
\hline & 0.316 & 0.754 & 0.246 & 0.575 & 0.390 \\
\hline Observations & 6352 & 1554 & 4798 & 1799 & 4553 \\
\hline \multicolumn{6}{|c|}{$\begin{array}{l}\text { Notes: The table shows the results of calculated average marginal effects after estimating equation (1), weighted } \\
\text { by weights as indicated in the panel sub-heading. The dependent variable is the logarithm or R\&D expenditures } \\
\text { as described in Section } 3.1 \text {. The variable of interest, 'Subsidy' indicates whether a firm is subsidy recipient or } \\
\text { not as defined in the panel sub-headline. Included are firm control variables as described in Section } 3.1 \text {. These } \\
\text { are firm size, firm size squared, firm age, firm age squared, firm rating, sales growth and export share. Firms are } \\
\text { defined as having low (high) firm financing constraints if their credit rating is among (weaker than) that of the } \\
25 \% \text { of the firms in the sample with the best rating score. For bank financing constraints, firms are defined as } \\
\text { having low (high) constraints if the firm is related to a bank that has a tangible common equity share which is } \\
\text { above (among) of that of the } 25 \% \text { of all German banks in the Bankscope data set with the lowest reserves. } \\
\text { Cluster-robust standard errors in parentheses, clustered at the firm level. Significance: * significant at the } 10 \% \\
\text { level, ** significant at the } 5 \% \text { level, *** significant at the } 1 \% \text { level. }\end{array}$} \\
\hline
\end{tabular}




\subsection{Definition of the subsidy variable}

Our main focus is on the effects of subsidies, but it has to be noted that this measure is not without problems. For example, it is possible that companies change between the status of subsidy recipient and non-subsidy recipient. In the next step, we define subsidy recipients as companies that have received subsidies in each period until the end of the financial crisis. This allows to test for the effect of firms that are always subsidy recipient and do not sort themselves into the subsidy recipient status in the financial crisis. As a further possibility, we define subsidy recipients as having received subsidies in the period before the crisis, i.e. in the years 2005 and/or 2006. Utilizing this definition of the treatment variable allows to test for the impact on firms that have been subsidy recipients independent of the financial crisis compared to those who never are subsidy recipient.

We present the results of the estimates of our Equation (1) extended by the two alternative measures for the definition of the subsidy recipients in Table 5. Panel A shows the results of the effects of the subsidies defined as permanent recipients and panel B the results based on the second alternative definition of the variable on the receipt of subsidies before the crisis. The results are very similar to those presented in Tables 2 and 3. The subsidies show additional effects on $R \& D$ expenditures when firms are linked to financially weak banks. Firms that are linked to "good" banks, with high capital reserves, continue to show no effect. ${ }^{16}$

\footnotetext{
${ }^{16}$ Similar results are obtained if we classify the firms as subsidy recipient if they received a subsidy (i) in the pre-crisis or crisis period (2002-2010). Moreover, we achieve similar results if we define firms as subsidy recipient if they received a subsidy from German states or national governments.
} 
Table 5: Definitions of the subsidy variable

\begin{tabular}{|c|c|c|c|c|c|}
\hline & \multicolumn{5}{|c|}{ Log of R\&D } \\
\hline & \multirow[t]{2}{*}{ Baseline } & \multicolumn{2}{|c|}{ Firm financing constraints } & \multicolumn{2}{|c|}{ Bank financing constraints } \\
\hline & & Low & High & Low & High \\
\hline \multicolumn{6}{|c|}{ Panel A: Received a subsidy in each year of the pre-crisis and crisis period (2004-2009) } \\
\hline Subsidy & $\begin{array}{l}4.495 * * * \\
(0.350)\end{array}$ & $\begin{array}{l}3.026 * * * \\
(0.510)\end{array}$ & $\begin{array}{l}4.307 * * * \\
(0.428)\end{array}$ & $\begin{array}{l}4.257 * * * \\
(0.603)\end{array}$ & $\begin{array}{l}4.535 * * * \\
(0.416)\end{array}$ \\
\hline Crisis & $\begin{array}{l}-1.689 * * * \\
(0.389)\end{array}$ & $\begin{array}{l}-1.166 * * \\
(0.588)\end{array}$ & $\begin{array}{l}-1.807 * * * \\
(0.480)\end{array}$ & $\begin{array}{l}-1.405^{* *} \\
(0.603)\end{array}$ & $\begin{array}{l}-1.944 * * * \\
(0.489)\end{array}$ \\
\hline PostCrisis & $\begin{array}{l}-1.895^{* * * *} \\
(0.519)\end{array}$ & $\begin{array}{l}-0.634 \\
(0.765)\end{array}$ & $\begin{array}{l}-2.311 * * * \\
(0.646)\end{array}$ & $\begin{array}{l}-1.262 \\
(0.891)\end{array}$ & $\begin{array}{l}-2.251 * * * \\
(0.651)\end{array}$ \\
\hline Subsidy $\times$ Crisis & $\begin{array}{l}0.954 * * \\
(0.467)\end{array}$ & $\begin{array}{l}0.513 \\
(0.735)\end{array}$ & $\begin{array}{l}1.246 * * \\
(0.553)\end{array}$ & $\begin{array}{l}-0.535 \\
(0.875)\end{array}$ & $\begin{array}{l}1.630 * * * \\
(0.550)\end{array}$ \\
\hline Subsidy $\times$ PostCrisis & $\begin{array}{l}1.137 * \\
(0.626)\end{array}$ & $\begin{array}{l}0.032 \\
(0.896)\end{array}$ & $\begin{array}{l}1.611 * * \\
(0.764)\end{array}$ & $\begin{array}{l}-0.490 \\
(1.119)\end{array}$ & $\begin{array}{l}1.739 * * \\
(0.778)\end{array}$ \\
\hline \multicolumn{6}{|c|}{$H_{0}:$ Subsidy $\times$ year $_{\mathrm{t}}=0 \forall \mathrm{t} \leq 2006 \mathrm{p}$-value } \\
\hline Observations & 4666 & 1174 & 3492 & 1314 & 3352 \\
\hline \multicolumn{6}{|c|}{ Panel B: Received a subsidy in the pre-crisis period (2005 and/or 2006) } \\
\hline Subsidy & $\begin{array}{l}3.838 * * * \\
(0.368)\end{array}$ & $\begin{array}{l}2.623 * * * \\
(0.723)\end{array}$ & $\begin{array}{l}3.639 * * * \\
(0.433)\end{array}$ & $\begin{array}{l}4.581 * * * \\
(0.691)\end{array}$ & $\begin{array}{l}3.714 * * * \\
(0.433)\end{array}$ \\
\hline Crisis & $\begin{array}{l}-1.682 * * * \\
(0.473)\end{array}$ & $\begin{array}{l}-0.342 \\
(0.603)\end{array}$ & $\begin{array}{l}-2.408 * * * \\
(0.605)\end{array}$ & $\begin{array}{l}-0.059 \\
(0.856)\end{array}$ & $\begin{array}{l}-1.830 * * * \\
(0.590)\end{array}$ \\
\hline PostCrisis & $\begin{array}{l}-1.397 * * \\
(0.625)\end{array}$ & $\begin{array}{l}-0.712 \\
(1.073)\end{array}$ & $\begin{array}{l}-1.730 * * \\
(0.782)\end{array}$ & $\begin{array}{l}0.233 \\
(0.904)\end{array}$ & $\begin{array}{l}-1.633 * * \\
(0.782)\end{array}$ \\
\hline Subsidy $\times$ Crisis & $\begin{array}{l}1.284 * * \\
(0.574)\end{array}$ & $\begin{array}{l}0.065 \\
(0.719)\end{array}$ & $\begin{array}{l}2.217 * * * \\
(0.700)\end{array}$ & $\begin{array}{l}-1.438 \\
(1.001)\end{array}$ & $\begin{array}{l}1.905 * * * \\
(0.681)\end{array}$ \\
\hline Subsidy $\times$ PostCrisis & $\begin{array}{l}0.785 \\
(0.725)\end{array}$ & $\begin{array}{l}0.079 \\
(1.149)\end{array}$ & $\begin{array}{l}1.189 \\
(0.887)\end{array}$ & $\begin{array}{l}-1.505 \\
(1.018)\end{array}$ & $\begin{array}{l}1.464 * \\
(0.866)\end{array}$ \\
\hline \multicolumn{6}{|c|}{$H_{0}:$ Subsidy $\times$ year $_{\mathrm{t}}=0 \forall \mathrm{t} \leq 2006 \mathrm{p}$-value } \\
\hline Observations & 3518 & 975 & 2543 & 965 & 2553 \\
\hline \multicolumn{6}{|c|}{$\begin{array}{l}\text { Notes: The table shows the results of calculated average marginal effects after estimating equation (1), weighted } \\
\text { by inverse probability weights, for financially constrained and unconstrained firms. The dependent variable is } \\
\text { the logarithm or R\&D expenditures as described in Section } 3.1 \text {. The variable of interest, 'Subsidy' indicates } \\
\text { whether a firm is subsidy recipient or not as defined in the panle sub-headline. Included are firm control } \\
\text { variables as described in Section } 3.1 \text {. These are firm size, firm size squared, firm age, firm age squared, firm } \\
\text { rating, sales growth and export share. Firms are defined as having low (high) firm financing constraints if their } \\
\text { credit rating is among (weaker than) that of the } 25 \% \text { of the firms in the sample with the best rating score. For } \\
\text { bank financing constraints, firms are defined as having low (high) constraints if the firm is related to a bank that } \\
\text { has a tangible common equity share which is above (among) of that of the } 25 \% \text { of all German banks in the } \\
\text { Bankscope data set with the lowest reserves. Cluster-robust standard errors in parentheses, clustered at the firm } \\
\text { level. Significance: * significant at the } 10 \% \text { level, } * * \text { significant at the } 5 \% \text { level, *** significant at the } 1 \% \text { level. }\end{array}$} \\
\hline
\end{tabular}

\subsection{Definition of firm constraints}

In a next set of tests, we account for the possibility that the results are driven by the definition of the firm financing constraints variables. For this purpose, we apply two tests. First, we redefine the cut point for constrained and not constrained firms according their rating value as of 2006. Thus, firms are characterized as low constrained if they have a rating value lower 
than the lowest $33 \%$ of firms in the sample. Those with high constraints are the remainder firms. The results are shown in Table 6, columns (3) and (4) and are comparable to those in Table 3. Second, we use the lagged rating value that is commonly applied as measure for financing constraints from the firm side (e.g., Czarnitzki and Hottenrott 2011a, 2011b). Firms are characterized as low constraint type if their rating value is better than that of the $25 \%$ of firms in the rating distribution with the weakest rating value. Respectively, high constraint firms are those with a weaker rating value. The results in Table 6, columns (5) and (6), again, point in the same direction as the baseline results. Thus, they are robust to this kind of change.

Table 6: Definitions of firm financing constraints

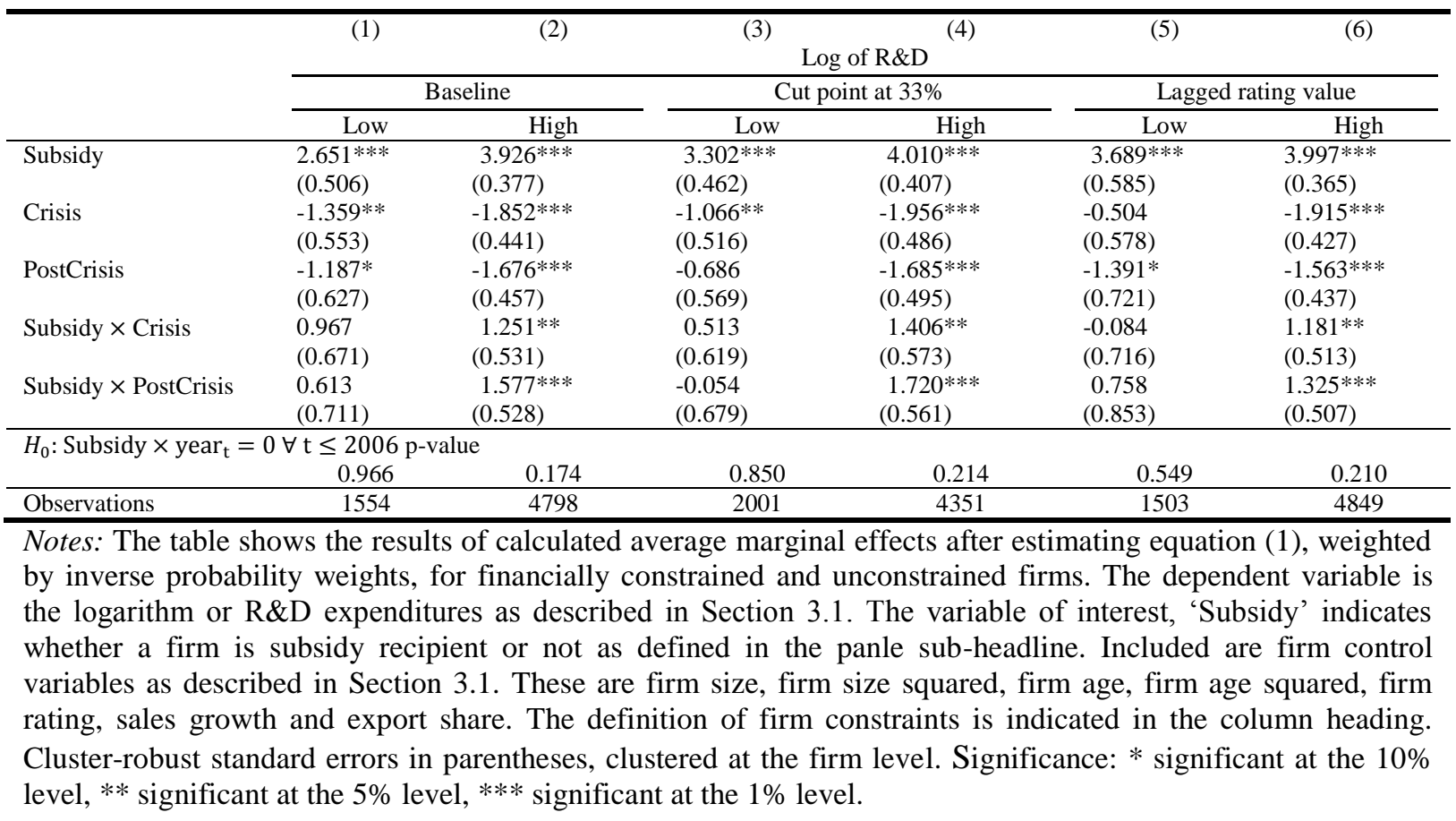

\subsection{Definition of bank constraints}

In the next section of robustness tests, two further measures of restrictions of the banks the firms are associated to are introduced: on the one hand the inverse of leverage computed as equity over total assets 'Equity over total assets' and on the other hand the ratio of capital funds over total assets 'Capital funds over total assets'. First, we apply the ratio of equity over total assets without the adjustments outline in Section 3.1. This variable is usually applied in 
the literature and reflects the inverse of leverage (e.g., Adrian et al. 2018; Berger and Bouwman 2013; Jiménez et al. 2012). Thus, a higher value of this measure indicates a higher capitalization of the bank and therefore a better ability to cope with shocks on financial markets (Adrian et al. 2018; Berger and Bouwman 2013). The results when applying equity over total assets as measure for bank financing constraints are shown in Table 7, columns (3) and (4). They are similar to the baseline results presented in Table 3.

Next, a variable ,Capital funds over total assets' is included, defined as the ratio of capital funds to total assets (Avdjiev et al. 2019; Nguyen 2012). Capital funds consist out of equity, hybrid capital and subordinated debts (Avdjiev et al. 2019). Subordinated debt and hybrid capital are part of the Tier 2 capital (e.g. Brinkmann and Horvitz 1995; Demirguc-Kunt et al. 2013; Ito and Sasaki 2002; Llorens and Martin-Oliver 2017; Montgomery 2005), which are able to alleviate losses (e.g. Llorens and Martin-Oliver 2017). Additionally, subordinated debt could be used for the purpose of increasing capital adequacy of banks (Ito and Sasaki 2002; Montgomery 2005). The ratio of capital funds to total assets can also serve as information on the capital adequacy of banks (Avdjiev et al. 2019; Nguyen 2012). The results in columns (5) and (6) of Table 7, are similar compared to those in Table 3. 
Table 7: Definitions of bank financing constraints

\begin{tabular}{|c|c|c|c|c|c|c|}
\hline & (1) & (2) & (3) & (4) & (5) & (6) \\
\hline & \multicolumn{6}{|c|}{$\log$ of $R \& D$} \\
\hline & \multicolumn{2}{|c|}{ Baseline } & \multicolumn{2}{|c|}{ Equity over total assets } & \multicolumn{2}{|c|}{ Capital funds over total assets } \\
\hline & Low & High & Low & High & Low & High \\
\hline \multirow[t]{2}{*}{ Subsidy } & $3.860 * * *$ & $3.999 * * *$ & $3.799 * * *$ & $4.059 * * *$ & $3.866^{* * *}$ & $3.996 * * *$ \\
\hline & $(0.542)$ & $(0.369)$ & $(0.471)$ & $(0.394)$ & $(0.544)$ & $(0.368)$ \\
\hline \multirow[t]{2}{*}{ Crisis } & $-1.490 * * *$ & $-1.753 * * *$ & $-1.554 * * *$ & $-1.755 * * *$ & $-1.448 * *$ & $-1.770 * * *$ \\
\hline & $(0.567)$ & $(0.436)$ & $(0.462)$ & $(0.475)$ & $(0.567)$ & $(0.436)$ \\
\hline \multirow{2}{*}{ PostCrisis } & $-1.844 * * *$ & $-1.553 * * *$ & $-1.415 * * *$ & $-1.840 * * *$ & $-1.791 * * *$ & $-1.572 * * *$ \\
\hline & $(0.682)$ & $(0.458)$ & $(0.515)$ & $(0.526)$ & $(0.683)$ & $(0.458)$ \\
\hline \multirow[t]{2}{*}{ Subsidy $\times$ Crisis } & 0.078 & $1.448 * * *$ & 0.020 & $1.495 * * *$ & 0.034 & $1.466 * * *$ \\
\hline & $(0.771)$ & $(0.510)$ & $(0.666)$ & $(0.537)$ & $(0.775)$ & $(0.509)$ \\
\hline \multirow[t]{2}{*}{ Subsidy $\times$ PostCrisis } & 1.293 & $1.293 * *$ & 0.714 & $1.654 * * *$ & 1.259 & $1.310 * *$ \\
\hline & $(0.858)$ & $(0.526)$ & $(0.636)$ & $(0.582)$ & $(0.860)$ & $(0.526)$ \\
\hline \multicolumn{7}{|c|}{$H_{0}$ : Subsidy $\times$ year $_{\mathrm{t}}=0 \forall \mathrm{t} \leq 2006 \mathrm{p}$-value } \\
\hline & $0 . \overline{931}$ & 0.250 & 0.876 & 0.212 & 0.909 & 0.245 \\
\hline Observations & 1799 & 4553 & 2642 & 3710 & 1790 & 4562 \\
\hline
\end{tabular}

Notes: The table shows the results of calculated average marginal effects after estimating equation (1), weighted by inverse probability weights, for financially constrained and unconstrained firms. The dependent variable is the logarithm or R\&D expenditures as described in Section 3.1. The variable of interest, 'Subsidy' indicates whether a firm is subsidy recipient or not as defined in the panel sub-headline. Included are firm control variables as described in Section 3.1. These are firm size, firm size squared, firm age, firm age squared, firm rating, sales growth and export share. For bank financing constraints, firms are defined as having low (high) constraints if the firm is related to a bank that has a tangible common equity share which is above (among) of that of the $25 \%$ of all German banks in the Bankscope data set with the lowest reserves. Cluster-robust standard errors in parentheses, clustered at the firm level. Significance: * significant at the $10 \%$ level, ** significant at the $5 \%$ level, $* * *$ significant at the $1 \%$ level.

\section{Conclusion}

We analyze the effects of subsidies on R\&D during the financial crisis, a period with exceptionally severe problems in financing innovation projects. Our study combines different sources of financing constraints for firms to investigate the effect of subsidies on R\&D. First, we investigate the role of financial constraints in the form of restrictions faced by the firms themselves, and second, restrictions by the banks of the firms under consideration. The restrictions at the firm level are represented by credit ratings and the financial restrictions of the banks by their crisis precaution measures in the form of capital reserves. The aim of the study is to identify the effects of the two types of financial constraints and to examine to what extent the receipt of subsidies can help to mitigate or fully compensate for the negative effects of the constraints.

Our findings show that firms which receive subsidies reduce $R \& D$ expenditures during the financial crisis to a lower degree and did not suffer from a (generally observed) stronger 
impact of financing constraints on $\mathrm{R} \& \mathrm{D}$ in that period. We find that firms with weak credit ratings reduce $R \& D$ in the crisis provided they get subsidized to a lower degree compared to not subsidized firms and the period before the crisis. Moreover, firms which are related to a low capitalized bank also show no larger intensity of financing constraints for R\&D in the financial crisis if they are classified as subsidy recipient. This in result shows that subsidies are not only mitigating financing constraints, but at least partically compensate them.

This result underlines the importance of $R \& D$ subsidies in coping with the consequences of difficulties in financing. In the case of the financial crisis, some of the problems were not caused by the companies themselves, but by the banks. Whatever the cause of the problems, the relevance of public subsidies for the continuity of R\&D investments even in bad times is an important result for economic policy. 


\section{References}

Abadie, A., \& Cattaneo, M. D. (2018). Econometric methods for program evaluation. Annual Review of Economics, 10, 465-503.

Acemoglu, D.; Autor, D. H. and Lyle, D., 2004, Women, War, and Wages: The Effect of Female Labor Supply on the Wage Structure At Midcentury, Journal of Political Economy, 112(3), pp. 497-551.

Adrian, T., Kiff, J., and Shin, H. S. (2018). Liquidity, Leverage, and Regulation 10 Years After the Global Financial Crisis. Annual Review of Financial Economics, 10, 1-24.

Aguiar, L., \& Gagnepain, P. (2017). European cooperative R\&D and firm performance: Evidence based on funding differences in key actions. International journal of industrial organization, 53, 1-31.

Almus, M., \& Czarnitzki, D. (2003). The effects of public R\&D subsidies on firms' innovation activities: the case of Eastern Germany. Journal of Business \& Economic Statistics, 21(2), 226-236.

Amore, M.D., (2015), Companies Learning to Innovate in Recessions, Research Policy, 44(8), 1574-1583.

Archibugi, D., Filippetti, A., and Frenz, M. (2013a). Economic crisis and innovation: Is destruction prevailing over accumulation?. Research Policy, 42(2), 303-314.

Archibugi, D., Filippetti, A., and Frenz, M (2013b). The impact of the economic crisis on innovation: evidence from Europe. Technological Forecasting and Social Change, 80(7), 1247-1260.

Aristei, D., Sterlacchini, A., \& Venturini, F. (2017). Effectiveness of R\&D subsidies during the crisis: firm-level evidence across EU countries. Economics of Innovation and new Technology, 26(6), 554-573.

Becker, B. (2015). Public R\&D policies and private R\&D investment: A survey of the empirical evidence. Journal of Economic Surveys, 29(5), 917-942.

Berger, A. N. and Bouwman, C. H. (2013). How Does Capital Affect Bank Performance during Financial Crises? Journal of Financial Economics, 109 (1), 146-176.

Brinkmann, E. J., \& Horvitz, P. M. (1995). Risk-based capital standards and the credit crunch. Journal of Money, Credit and Banking, 27(3), 848-863.

Bronzini, R., \& Piselli, P. (2016). The impact of R\&D subsidies on firm innovation. Research Policy, 45(2), 442-457.

Buch, C. M. and Prieto, E. (2014). Do Better Capitalized Banks Lend Less? Long-Run Panel Evidence from Germany. International Finance, 17 (1), 1-23.

Busom, I. (2000). An empirical evaluation of the effects of R\&D subsidies. Economics of innovation and new technology, 9(2), 111-148. 
Campello, M., Graham, J.R., and Harvey, C.R. (2010). The real effects of financial constraints: evidence from a financial crisis. Journal of Financial Economics, 97, 470487.

Clausen, T. H. (2009). Do subsidies have positive impacts on R\&D and innovation activities at the firm level?. Structural change and economic dynamics, 20(4), 239-253.

Crump, R. K., Hotz, V. J., Imbens, G. W., \& Mitnik, O. A. (2009). Dealing with limited overlap in estimation of average treatment effects. Biometrika, 96(1), 187-199.

Czarnitzki, D., \& Hottenrott, H. (2010). Financing Constraints for Industrial Innovation: What Do We Know?. Review of Business and Economic Literature, 55(3), 346-363.

Czarnitzki, D., \& Hottenrott, H. (2011a). R\&D investment and financing constraints of small and medium-sized firms. Small Business Economics, 36, 65-83.

Czarnitzki, D., \& Hottenrott, H. (2011b). Financial constrinats: Routine verus cutting edge R\&D investment. Journal of Economics and Management Strategy, 20, 121-157.

Czarnitzki, D. and Kraft, K. (2012), Spillovers of innovative activity and their profitability, Oxford Economic Paper, 73, 509-538.

Czarnitzki, D., \& Lopes-Bento, C. (2013). Value for money? New microeconometric evidence on public R\&D grants in Flanders. Research Policy, 42(1), 76-89.

David, P. A., Hall, B. H., \& Toole, A. A. (2000). Is public R\&D a complement or substitute for private R\&D? A review of the econometric evidence. Research policy, 29(4-5), 497-529.

Diamond, D. W. and Rajan, R. G. (2000). A Theory of Bank Capital. The Journal of Finance, 55 (6), 2431-2465.

Dietrich, D., \& Vollmer, U. (2012). Are universal banks bad for financial stability? Germany during the world financial crisis. The Quarterly Review of Economics and Finance, $52(2), 123-134$.

Duchin, R.; Ozbas, O. and Sensoy, B. A., 2010, Costly External Finance, Corporate Investment, and the Subprime Mortgage Credit Crisis, Journal of Financial Economics, 97(3), pp. 418-435.

Filippetti, A. and Archibugi, D., (201, Innovation in Times of Crisis: National Systems of Innovation, Structure, and Demand, Research Policy, 40(2), pp. 179-192.

Hall, B. H. and Lerner, J. (2010). The Financing of R\&D and Innovation. In B. H. Hall \& N. Rosenberg (Eds.), Handbook of the Economics of Innovation (pp. 609-639). NorthHolland: Elsevier.

Hall, B. H., Moncada-Paternò-Castello, P., Montresor, S., \& Vezzani, A. (2016). Financing constraints, R\&D investments and innovative performances: new empirical evidence at the firm level for Europe.

Hünermund, P., \& Czarnitzki, D. (2019). Estimating the causal effect of R\&D subsidies in a pan-European program. Research Policy, 48(1), 115-124. 
Gambacorta, L. and Mistrulli, P. E. (2004). Does Bank Capital Affect Lending Behavior? Journal of Financial Intermediation, 13 (4), 436-457.

Gambacorta, L. and Shin, H. S. (2018). Why Bank Capital Matters for Monetary Policy. Journal of Financial Intermediation, 35, 17-29.

Hottenrott, H., Lins, E., \& Lutz, E. (2018). Public subsidies and new ventures' use of bank loans. Economics of Innovation and new technology, 27(8), 786-808.

Howell, S. T. (2017). Financing innovation: evidence from R\&D grants. American Economic Review, 107(4), 1136-64.

Hud, M., \& Hussinger, K. (2015). The impact of R\&D subsidies during the crisis. Research Policy, 44(10), 1844-1855.

Hyytinen, A., \& Toivanen, O. (2005). Do financial constraints hold back innovation and growth?: Evidence on the role of public policy. Research Policy, 34(9), 1385-1403.

Imbens, G. W. and Wooldridge, J. M., 2009, Recent Developments in the Econometrics of Program Evaluation, Journal of Economic Literature, 47(1), pp. 5-86.

Ito, T., \& Sasaki, Y. N. (2002). Impacts of the Basle capital standard on Japanese banks' behavior. Journal of the Japanese and International Economies, 16(3), 372-397.

Ivashina, V., \& Scharfstein, D. (2010). Bank lending during the financial crisis of 2008. Journal of Financial economics, 97(3), 319-338.

Jiménez, G., Ongena, S., Peydro, J. L., and Saurina, J. (2012). Credit Supply and Monetary Policy: Identifying the Bank Balance-Sheet Channel with Loan Applications. American Economic Review, 102 (5), 2301-26.

Jirjahn, U. and Kraft, K. (2011), Do spillovers stimulate incremental or drastic innovation? Hypotheses and evidence from German establishment data, Oxford Bulletin of Economics and Statistics, 73, 509-538.

Kleer, R. (2010). Government R\&D subsidies as a signal for private investors. Research Policy, 39(10), 1361-1374.

Knudsen, E. S. and Lien, L. B. (2014). Investments in Recessions. Advances in Strategic Management, 31, 3-36.

Lach, S. (2002). Do R\&D subsidies stimulate or displace private R\&D? Evidence from Israel. The journal of industrial economics, 50(4), 369-390.

Lee, S., Sameen, H., and Cowling, M. (2015). Access to Finance for Innovative SMEs Since the Financial Crisis. Research Policy, 44 (2), 370-380.

Li, F., Thomas, L. E., \& Li, F. (2019). Addressing extreme propensity scores via the overlap weights. American journal of epidemiology, 188(1), 250-257.

Llorens, V., \& Martin-Oliver, A. (2017). Determinants of bank's financing choices under capital regulation. SERIEs, 8(3), 287-309. 
Meuleman, M., \& De Maeseneire, W. (2012). Do R\&D subsidies affect SMEs' access to external financing?. Research Policy, 41(3), 580-591.

Montgomery, H. (2005). The effect of the Basel Accord on bank portfolios in Japan. Journal of the Japanese and international economies, 19(1), 24-36.

Nanda, R. and Nicholas, T. (2014). Did Bank Distress Stifle Innovation during the Great Depression? Journal of Financial Economics, 114 (2), 273-292.

Paunov, C. (2012). The global crisis and firms' investments in innovation. Research Policy, 41(1), 24-35.

Peters, B., Roberts, M. J., and Vuong, V. A. (2017). Dynamic R\&D Choice and the Impact of the Firm's Financial Strength. Economics of Innovation and New Technology, 26 (12), 134-149.

Schäfer, D., \& Stephan, A. (2017). Innovation and Investment Funding in the post-crisis period: have financing patterns and financial constraints of German firms changed?. Vierteljahrshefte zur Wirtschaftsforschung, 86(1), 129-142.

Takalo, T., \& Tanayama, T. (2010). Adverse selection and financing of innovation: is there a need for R\&D subsidies?. The Journal of Technology Transfer, 35(1), 16-41.

Waldinger, F., 2010, 'Quality Matters: The Expulsion of Professors and the Consequences For PhD Student Outcomes in Nazi Germany,' Journal of Political Economy, 118(4),

Wooldridge, J. M. (2010). Econometric Analysis of Cross Section and Panel Data (2 ed.). Cambridge, MA: MIT Press.

Zúñiga-Vicente, J. Á., Alonso-Borrego, C., Forcadell, F. J., \& Galán, J. I. (2014). Assessing the effect of public subsidies on firm R\&D investment: a survey. Journal of Economic Surveys, 28(1), 36-67. 


\section{Appendix A - Descriptive statistics}

Table A1: Distribution of firms over federal states

\begin{tabular}{lcc}
\hline Name & Firms & Percentage share \\
\hline Baden-Wuerttemberg & 430 & 14.686 \\
Bavaria & 411 & 14.037 \\
Berlin & 104 & 3.552 \\
Brandenburg & 111 & 3.791 \\
Bremen & 47 & 1.605 \\
Hamburg & 54 & 1.844 \\
Hesse & 178 & 6.079 \\
Lower Saxony & 212 & 7.240 \\
Mecklenburg-Vorpommern & 55 & 1.878 \\
North Rhine-Westphalia & 491 & 16.769 \\
Rhineland-Palatinate & 94 & 3.210 \\
Saarland & 28 & 0.956 \\
Saxony & 340 & 11.612 \\
Saxony-Anhalt & 134 & 4.577 \\
Schleswig-Holstein & 59 & 2.015 \\
Thuringia & 180 & 6.148 \\
\hline Total & 2928 & 100 \\
\hline
\end{tabular}

Table A2: Distribution of firms over industries

\begin{tabular}{lcrc}
\hline Name & NACE Rev. 2.0 code & Firms & Percentage share \\
\hline Mining & $5-9,19,35$ & 92 & 3.142 \\
Food/Tobacco & $10-12$ & 104 & 3.552 \\
Textiles & $13-15$ & 118 & 4.030 \\
Wood/Paper & $16-17$ & 104 & 3.552 \\
Chemicals & $20-21$ & 195 & 6.660 \\
Plastics & 22 & 136 & 4.645 \\
Glass/Ceramics & 23 & 86 & 2.937 \\
Metals & $24-25$ & 275 & 9.392 \\
Electrical equipment & $26-27$ & 447 & 15.266 \\
Machinery & 28 & 326 & 11.134 \\
Retail/Automobile & $29-30$ & 114 & 3.893 \\
Furniture/Toys/Medical technology/Maintenance & $31-33$ & 214 & 7.309 \\
Energy / Water & $36-39$ & 61 & 2.083 \\
Media services & $18,58-60$ & 83 & 2.835 \\
IT/Telecommunications & $61-63$ & 231 & 7.889 \\
Technical services/R\&D services & $71-72$ & 268 & 9.153 \\
Consulting/Advertising & $69,70.2,73$ & 74 & 2.527 \\
\hline Total & & 2928 & 100 \\
\hline
\end{tabular}


Appendix B - Selection in the subsidy recipient status 
Table B1: Probit estimation results to obtain the propensity score for the construction of the inverse probability weights

\begin{tabular}{|c|c|c|c|c|c|c|c|c|c|}
\hline & (1) & (2) & (3) & (4) & (5) & (6) & (7) & (8) & (9) \\
\hline & 2004 & 2005 & 2006 & 2007 & 2008 & 2009 & 2010 & 2011 & 2012 \\
\hline \multirow[t]{2}{*}{ Firm size } & 0.186 & -0.088 & -0.169 & 0.192 & -0.244 & -0.061 & 0.088 & 0.766 & $0.818 * * *$ \\
\hline & $(0.187)$ & $(0.139)$ & $(0.138)$ & $(0.536)$ & $(0.236)$ & $(0.334)$ & $(0.131)$ & $(0.735)$ & $(0.264)$ \\
\hline \multirow[t]{2}{*}{ Firm size squared } & -0.022 & 0.004 & 0.008 & -0.198 & $0.092 *$ & 0.070 & -0.001 & 0.005 & $-0.055 * * *$ \\
\hline & $(0.027)$ & $(0.004)$ & $(0.006)$ & $(0.219)$ & $(0.055)$ & $(0.077)$ & $(0.014)$ & $(0.425)$ & $(0.019)$ \\
\hline \multirow[t]{2}{*}{ Firm age } & -0.008 & -0.003 & -0.007 & -0.011 & $-0.010 * *$ & -0.009 & $-0.013 * *$ & 0.004 & $-0.015 * *$ \\
\hline & $(0.006)$ & $(0.007)$ & $(0.005)$ & $(0.007)$ & $(0.005)$ & $(0.010)$ & $(0.005)$ & $(0.010)$ & $(0.006)$ \\
\hline \multirow[t]{2}{*}{ Firm age squared } & 0.000 & 0.000 & 0.000 & 0.000 & $0.000 * *$ & 0.000 & $0.000 * *$ & -0.000 & $0.000 *$ \\
\hline & $(0.000)$ & $(0.000)$ & $(0.000)$ & $(0.000)$ & $(0.000)$ & $(0.000)$ & $(0.000)$ & $(0.000)$ & $(0.000)$ \\
\hline \multirow[t]{2}{*}{ Part of firm group } & -0.077 & 0.061 & 0.023 & -0.152 & -0.136 & 0.141 & $-0.204 * *$ & $-0.362 * *$ & $-0.222 *$ \\
\hline & $(0.110)$ & $(0.135)$ & $(0.095)$ & $(0.142)$ & $(0.099)$ & $(0.159)$ & $(0.094)$ & $(0.173)$ & $(0.115)$ \\
\hline \multirow[t]{2}{*}{ Export share } & $0.009 * * *$ & 0.004 & 0.002 & $0.006 * *$ & 0.003 & 0.004 & $0.006 * * *$ & 0.003 & $0.005 * *$ \\
\hline & $(0.002)$ & $(0.003)$ & $(0.002)$ & $(0.003)$ & $(0.002)$ & $(0.003)$ & $(0.002)$ & $(0.004)$ & $(0.002)$ \\
\hline \multirow[t]{2}{*}{ Sales growth } & -0.045 & -0.021 & $0.155^{*}$ & 0.130 & 0.040 & 0.085 & 0.141 & 0.377 & 0.081 \\
\hline & $(0.071)$ & $(0.024)$ & $(0.080)$ & $(0.117)$ & $(0.180)$ & $(0.171)$ & $(0.119)$ & $(0.247)$ & $(0.138)$ \\
\hline \multirow[t]{2}{*}{ Rating } & 0.001 & -0.001 & -0.001 & -0.002 & $-0.002 *$ & 0.002 & -0.001 & $-0.004 *$ & -0.001 \\
\hline & $(0.001)$ & $(0.002)$ & $(0.001)$ & $(0.002)$ & $(0.001)$ & $(0.002)$ & $(0.001)$ & $(0.002)$ & $(0.001)$ \\
\hline \multirow[t]{2}{*}{ Tangible common equity } & -0.220 & -0.271 & 0.099 & 0.313 & $0.509 *$ & $1.297 * *$ & $0.984 * * *$ & 0.198 & 0.401 \\
\hline & $(0.223)$ & $(0.258)$ & $(0.210)$ & $(0.355)$ & $(0.279)$ & $(0.632)$ & $(0.368)$ & $(0.646)$ & $(0.319)$ \\
\hline \multirow[t]{2}{*}{ Equity over total assets } & 25.136 & 30.195 & -7.388 & -24.473 & $-54.984 *$ & $-125.297 *$ & $-100.809 * * *$ & -19.678 & -41.158 \\
\hline & $(23.473)$ & $(27.189)$ & $(22.027)$ & $(37.069)$ & $(28.932)$ & $(64.577)$ & $(37.837)$ & $(66.407)$ & $(33.348)$ \\
\hline \multirow[t]{2}{*}{ Capital funds } & $-0.075^{*}$ & -0.055 & -0.041 & $-0.141 * * *$ & -0.035 & -0.071 & -0.036 & -0.005 & 0.004 \\
\hline & $(0.043)$ & $(0.049)$ & $(0.036)$ & $(0.050)$ & $(0.035)$ & $(0.054)$ & $(0.032)$ & $(0.051)$ & $(0.037)$ \\
\hline \multirow{2}{*}{ Constant } & $-0.799 *$ & -0.339 & -0.504 & 0.218 & 0.173 & $-2.231 * * *$ & 0.333 & -0.226 & -0.178 \\
\hline & $(0.477)$ & $(0.609)$ & $(0.476)$ & $(0.742)$ & $(0.466)$ & $(0.820)$ & $(0.422)$ & $(0.845)$ & $(0.496)$ \\
\hline Industry fixed effects & Yes & Yes & Yes & Yes & Yes & Yes & Yes & Yes & Yes \\
\hline Federal state fixed effects & Yes & Yes & Yes & Yes & Yes & Yes & Yes & Yes & Yes \\
\hline Ps. R-squared & 0.203 & 0.182 & 0.123 & 0.187 & 0.134 & 0.202 & 0.131 & 0.171 & 0.203 \\
\hline Observations & 842 & 562 & 970 & 523 & 1008 & 397 & 1066 & 354 & 715 \\
\hline
\end{tabular}

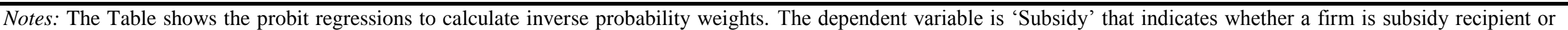
not. Standard errors are shown in parantheses. Significance: * significant at the $10 \%$ level, ** significant at the 5\% level, *** significant at the $1 \%$ level. 
Table B2: Comparison of means after matching

\begin{tabular}{|c|c|c|c|c|c|c|c|c|c|}
\hline & $\begin{array}{c}(1) \\
2004\end{array}$ & $\begin{array}{c}(2) \\
2005\end{array}$ & $\begin{array}{c}(3) \\
2006\end{array}$ & $\begin{array}{c}(4) \\
2007\end{array}$ & $\begin{array}{c}(5) \\
2008\end{array}$ & $\begin{array}{c}(6) \\
2009\end{array}$ & $\begin{array}{c}(7) \\
2010\end{array}$ & $\begin{array}{c}(8) \\
2011\end{array}$ & $\begin{array}{c}(9) \\
2012\end{array}$ \\
\hline \multirow[t]{2}{*}{ Firm size } & 0.020 & -0.001 & -0.009 & -0.009 & -0.003 & -0.005 & 0.010 & -0.006 & -0.013 \\
\hline & $(0.362)$ & $(-0.014)$ & $(-0.335)$ & $(-0.189)$ & $(-0.081)$ & $(-0.130)$ & $(0.275)$ & $(-0.194)$ & $(-0.353)$ \\
\hline \multirow[t]{2}{*}{ Firm size squared } & -0.000 & -0.271 & -0.155 & -0.117 & -0.019 & -0.023 & 0.071 & -0.018 & -0.172 \\
\hline & $(-0.000)$ & $(-1.322)$ & $(-1.509)$ & $(-0.798)$ & $(-0.153)$ & $(-0.300)$ & $(0.274)$ & $(-0.552)$ & $(-0.358)$ \\
\hline \multirow[t]{2}{*}{ Firm age } & 3.273 & 2.146 & 1.694 & -1.343 & 0.894 & 4.136 & 0.519 & 0.418 & 1.854 \\
\hline & $(0.819)$ & $(0.501)$ & $(0.600)$ & $(-0.433)$ & $(0.372)$ & $(0.547)$ & $(0.231)$ & $(0.111)$ & $(0.547)$ \\
\hline \multirow[t]{2}{*}{ Firm age squared } & 326.790 & 245.373 & 154.111 & -148.649 & 104.839 & 594.018 & 51.357 & 14.280 & 183.906 \\
\hline & $(0.682)$ & $(0.432)$ & $(0.420)$ & $(-0.366)$ & $(0.352)$ & $(0.545)$ & $(0.184)$ & $(0.028)$ & $(0.414)$ \\
\hline \multirow[t]{2}{*}{ Part of firm group } & 0.041 & 0.012 & 0.000 & 0.017 & -0.013 & 0.029 & 0.006 & -0.006 & -0.023 \\
\hline & $(0.852)$ & $(0.217)$ & $(0.011)$ & $(0.311)$ & $(-0.340)$ & $(0.414)$ & $(0.176)$ & $(-0.092)$ & $(-0.505)$ \\
\hline \multirow[t]{2}{*}{ Sales growth } & -0.150 & 1.068 & -0.026 & -0.208 & -0.118 & 0.224 & 0.160 & -0.299 & -1.349 \\
\hline & $(-0.063)$ & $(0.357)$ & $(-0.013)$ & $(-0.075)$ & $(-0.061)$ & $(0.074)$ & $(0.090)$ & $(-0.095)$ & $(-0.539)$ \\
\hline \multirow[t]{2}{*}{ Export share } & -0.031 & -0.086 & -0.020 & 0.002 & -0.006 & -0.008 & 0.012 & 0.001 & -0.016 \\
\hline & $(-0.753)$ & $(-0.525)$ & $(-0.668)$ & $(0.075)$ & $(-0.308)$ & $(-0.210)$ & $(0.338)$ & $(0.041)$ & $(-0.615)$ \\
\hline \multirow[t]{2}{*}{ Rating } & -4.725 & -2.905 & -0.460 & 1.233 & -0.070 & -2.118 & 0.811 & -0.973 & -1.442 \\
\hline & $(-0.892)$ & $(-0.583)$ & $(-0.146)$ & $(0.290)$ & $(-0.021)$ & $(-0.356)$ & $(0.194)$ & $(-0.224)$ & $(-0.433)$ \\
\hline \multirow[t]{2}{*}{ Tangible common equity } & -0.140 & -0.161 & 0.005 & -0.100 & -0.019 & 0.124 & 0.008 & 0.016 & 0.064 \\
\hline & $(-0.778)$ & $(-0.714)$ & $(0.030)$ & $(-0.461)$ & $(-0.127)$ & $(0.484)$ & $(0.057)$ & $(0.076)$ & $(0.391)$ \\
\hline \multirow[t]{2}{*}{ Equity over total assets } & -0.001 & -0.002 & 0.000 & -0.001 & -0.000 & 0.001 & 0.000 & 0.000 & 0.001 \\
\hline & $(-0.814)$ & $(-0.752)$ & $(0.017)$ & $(-0.486)$ & $(-0.179)$ & $(0.358)$ & $(0.012)$ & $(0.067)$ & $(0.354)$ \\
\hline \multirow[t]{2}{*}{ Capital funds } & -0.144 & -0.229 & -0.008 & -0.184 & -0.001 & 0.085 & -0.027 & -0.016 & 0.073 \\
\hline & $(-0.755)$ & $(-1.032)$ & $(-0.050)$ & $(-0.813)$ & $(-0.010)$ & $(0.329)$ & $(-0.202)$ & $(-0.063)$ & $(0.385)$ \\
\hline Observations & 833 & 558 & 953 & 513 & 1002 & 394 & 1059 & 338 & 702 \\
\hline
\end{tabular}

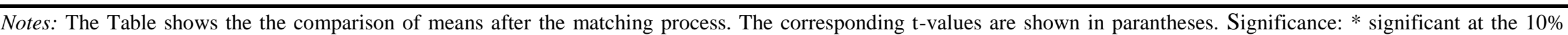
level, ** significant at the $5 \%$ level, $* * *$ significant at the $1 \%$ level. 


\section{Appendix C - Tables - Effect heterogeneity over time}

Table C1: Heterogeneity of the effect over time

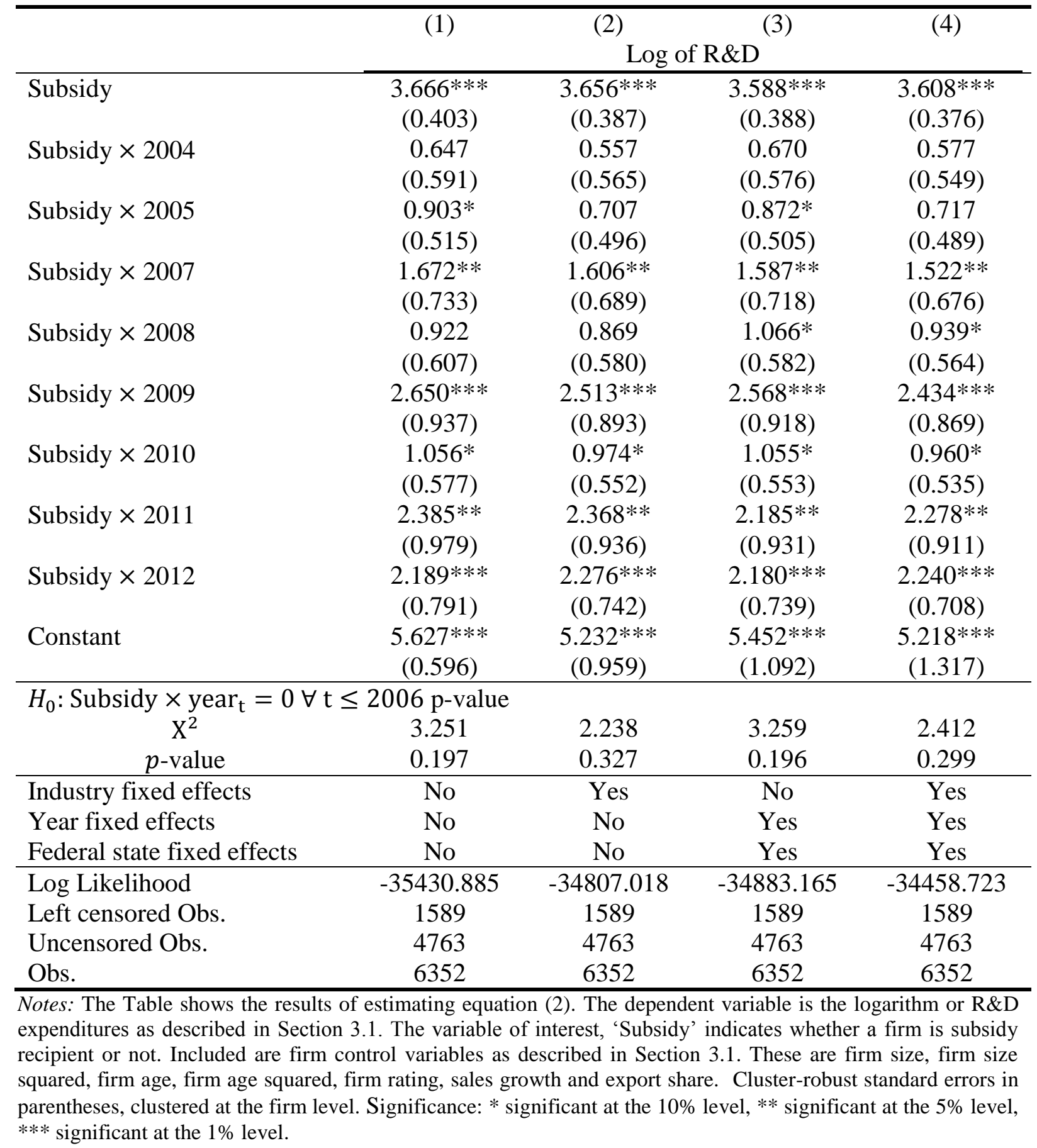


Table C1: Heterogeneity of the effect over time

\begin{tabular}{|c|c|c|c|c|}
\hline & (1) & (2) & (3) & (4) \\
\hline & \multicolumn{4}{|c|}{ Log of R\&D } \\
\hline & \multicolumn{2}{|c|}{ Firm financing constraints } & \multicolumn{2}{|c|}{ Bank financing constraints } \\
\hline & Low & High & Low & High \\
\hline \multirow[t]{2}{*}{ Subsidy } & $2.670 * * *$ & $3.360 * * *$ & $3.806^{* * *}$ & $3.486 * * *$ \\
\hline & $(0.587)$ & $(0.457)$ & $(0.684)$ & $(0.450)$ \\
\hline \multirow{2}{*}{ Subsidy $\times 2004$} & 0.053 & $1.122 *$ & -0.051 & 0.857 \\
\hline & $(0.822)$ & $(0.662)$ & $(0.950)$ & $(0.648)$ \\
\hline \multirow[t]{2}{*}{ Subsidy $\times 2005$} & -0.133 & 0.758 & 0.263 & 0.840 \\
\hline & $(0.646)$ & $(0.560)$ & $(0.782)$ & $(0.574)$ \\
\hline \multirow[t]{2}{*}{ Subsidy $\times 2007$} & 1.257 & $1.941 * *$ & 0.922 & $1.831 * *$ \\
\hline & (1.074) & $(0.806)$ & $(1.448)$ & $(0.742)$ \\
\hline \multirow[t]{2}{*}{ Subsidy $\times 2008$} & 1.163 & $1.117 *$ & -0.222 & $1.555^{* *}$ \\
\hline & $(0.958)$ & $(0.654)$ & $(0.999)$ & $(0.660)$ \\
\hline \multirow[t]{2}{*}{ Subsidy $\times 2009$} & -0.050 & $3.489 * * *$ & 0.399 & $3.054 * * *$ \\
\hline & $(0.930)$ & $(1.084)$ & (1.409) & $(1.019)$ \\
\hline \multirow{2}{*}{ Subsidy $\times 2010$} & -0.058 & $1.538 * *$ & $1.930 *$ & 0.747 \\
\hline & $(0.829)$ & $(0.623)$ & $(1.003)$ & $(0.631)$ \\
\hline \multirow[t]{2}{*}{ Subsidy $\times 2011$} & 1.320 & $2.811 * * *$ & 0.899 & $2.726 * *$ \\
\hline & $(1.657)$ & $(1.072)$ & $(1.711)$ & $(1.114)$ \\
\hline \multirow[t]{2}{*}{ Subsidy $\times 2012$} & 1.444 & $2.777 * * *$ & 0.610 & $2.905 * * *$ \\
\hline & $(1.241)$ & $(0.813)$ & $(1.515)$ & $(0.789)$ \\
\hline \multirow[t]{2}{*}{ Constant } & $5.056 * *$ & 1.636 & $6.491 * * *$ & $5.069 * * *$ \\
\hline & $(2.102)$ & $(2.136)$ & $(2.139)$ & $(1.631)$ \\
\hline \multicolumn{5}{|c|}{$H_{0}$ : Subsidy $\times$ year $_{\mathrm{t}}=0 \forall \mathrm{t} \leq 2006 \mathrm{p}$-value } \\
\hline $\mathrm{X}^{2}$ & 0.069 & 3.496 & 0.142 & 2.774 \\
\hline$p$-value & 0.966 & 0.174 & 0.931 & 0.250 \\
\hline Industry fixed effects & Yes & Yes & Yes & Yes \\
\hline Year fixed effects & Yes & Yes & Yes & Yes \\
\hline Federal state fixed effects & Yes & Yes & Yes & Yes \\
\hline Log Likelihood & -8580.270 & -25492.474 & -9607.930 & -24677.895 \\
\hline Left censored Obs. & 305 & 1284 & 506 & 1083 \\
\hline Uncensored Obs. & 1249 & 3514 & 1293 & 3470 \\
\hline Obs. & 1554 & 4798 & 1799 & 4553 \\
\hline \multicolumn{5}{|c|}{$\begin{array}{l}\text { Notes: The Table shows the results of estimating equation (2) for firms with low and high constraints. The } \\
\text { dependent variable is the logarithm or R\&D expenditures as described in Section } 3.1 \text {. The variable of interest, } \\
\text { 'Subsidy' indicates whether a firm is subsidy recipient or not. Included are firm control variables as described in } \\
\text { Section 3.1. These are firm size, firm size squared, firm age, firm age squared, firm rating, sales growth and } \\
\text { export share. Firms are defined as having low (high) firm financing constraints if their credit rating is among } \\
\text { (weaker than) that of the } 25 \% \text { of the firms in the sample with the best rating score. For bank financing constraints, } \\
\text { firms are defined as having low (high) constraints if the firm is related to a bank that has a tangible common } \\
\text { equity share which is above (among) of that of the } 25 \% \text { of all German banks in the Bankscope data set with the } \\
\text { lowest reserves. Cluster-robust standard errors in parentheses, clustered at the firm level. Significance: * } \\
\text { significant at the } 10 \% \text { level, ** significant at the } 5 \% \text { level, *** significant at the } 1 \% \text { level. }\end{array}$} \\
\hline
\end{tabular}


Download ZEW Discussion Papers from our ftp server:

https://www.zew.de/en/publications/zew-discussion-papers

or see:

https://www.ssrn.com/link/ZEW-Ctr-Euro-Econ-Research.html

https://ideas.repec.org/s/zbw/zewdip.html

//

ZEW - Leibniz-Zentrum für Europäische Wirtschaftsforschung GmbH Mannheim

ZEW - Leibniz Centre for European

Economic Research

L 7,1 68161 Mannheim · Germany

Phone +49621 1235-01

info@zew.de·zew.de

Discussion Papers are intended to make results of ZEW research promptly available to other economists in order to encourage discussion and suggestions for revisions. The authors are solely responsible for the contents which do not necessarily represent the opinion of the ZEW. 